Atmos. Chem. Phys., 13, 10933-10950, 2013

www.atmos-chem-phys.net/13/10933/2013/

doi:10.5194/acp-13-10933-2013

(c) Author(s) 2013. CC Attribution 3.0 License.

\title{
In situ submicron organic aerosol characterization at a boreal forest research station during HUMPPA-COPEC 2010 using soft and hard ionization mass spectrometry
}

\author{
A. L. Vogel ${ }^{1}$, M. Äijälä ${ }^{2}$, A. L. Corrigan ${ }^{3}$, H. Junninen ${ }^{2}$, M. Ehn ${ }^{2}$, T. Petäjä ${ }^{2}$, D. R. Worsnop ${ }^{2,5}$, M. Kulmala ${ }^{2}$, \\ L. M. Russell ${ }^{3}$, J. Williams ${ }^{4}$, and T. Hoffmann ${ }^{1}$ \\ ${ }^{1}$ Institute of Inorganic Chemistry and Analytical Chemistry, Johannes Gutenberg-University Mainz, 55128 Mainz, Germany \\ ${ }^{2}$ Department of Physics, University of Helsinki, 00014 Helsinki, Finland \\ ${ }^{3}$ Scripps Institution of Oceanography and the University of California, San Diego, La Jolla, CA 92093, USA \\ ${ }^{4}$ Department of Atmospheric Chemistry, Max Planck Institute for Chemistry, 55128 Mainz, Germany \\ ${ }^{5}$ Aerodyne Research Inc, Billerica, MA 01821, USA
}

Correspondence to: T. Hoffmann (t.hoffmann@uni-mainz.de)

Received: 25 June 2013 - Published in Atmos. Chem. Phys. Discuss.: 5 July 2013

Revised: 16 September 2013 - Accepted: 4 October 2013 - Published: 8 November 2013

\begin{abstract}
The chemical composition of submicron aerosol during the comprehensive field campaign HUMPPA-COPEC 2010 at Hyytiälä, Finland, is presented. The focus lies on online measurements of organic acids, which were achieved by using atmospheric pressure chemical ionization (APCI) ion trap mass spectrometry (IT-MS). These measurements were accompanied by aerosol mass spectrometry (AMS) measurements and Fourier transform infrared spectroscopy (FTIR) of filter samples, all showing a high degree of correlation. The soft ionization mass spectrometer alternated between gasphase measurements solely and measuring the sum of gas and particle phase.

The AMS measurements of $\mathrm{C}, \mathrm{H}$ and $\mathrm{O}$ elemental composition show that the aerosol during the campaign was highly oxidized, which appears reasonable due to high and prolonged radiation during the boreal summer measurement period as well as the long transport times of some of the aerosol. In order to contrast ambient and laboratory aerosol, an average organic acid pattern, measured by APCI-IT-MS during the campaign, was compared to terpene ozonolysis products in a laboratory reaction chamber. Identification of single organic acid species remains a major challenge due to the complexity of the boreal forest aerosol. Unambiguous online species identification was attempted by the combinatorial approach of identifying unique fragments in the $\mathrm{MS}^{2}$ mode of standards, and then comparing these results
\end{abstract}

with $\mathrm{MS}^{2}$ field spectra. During the campaign, unique fragments of limonene-derived organic acids (limonic acid and ketolimononic acid) and of the biomass burning tracer vanillic acid were detected. Other specific fragments (neutral loss of $28 \mathrm{Da}$ ) in the $\mathrm{MS}^{2}$ suggest the occurrence of semialdehydes.

Furthermore, an approach to determine the average molecular weight of the aerosol is presented. The campaign average organic molecular weight was determined to be $300 \mathrm{~g} \mathrm{~mol}^{-1}$. However, a plume of aged biomass burning aerosol, arriving at Hyytiälä from Russia, contained organic compounds up to $800 \mathrm{Da}\left(\overline{\mathrm{MW}}_{\mathrm{om}} \approx 450 \mathrm{~g} \mathrm{~mol}^{-1}\right.$ ), showing that the average molecular weight can vary significantly. The high measurement frequency of both AMS and APCI-ITMS enabled the partitioning of selected organic acids between gas and particle phase as a function of the total particulate mass to be quantified. Surprisingly high fractions of the higher molecular weight organic acids were observed to reside in the gas phase. These observations might be a consequence of large equilibration timescales for semi-solid boreal forest aerosol, as has been recently hypothesized by Shiraiwa and Seinfeld (2012). 


\section{Introduction}

The boreal forest biome is one of the major ecosystems on earth, accounting for one third of the world's forested area (Sabine et al., 2004). Due to biogenic volatile organic compound (BVOC) emissions from the vegetation, the boreal forest significantly affects the chemistry and physics of the atmosphere. Subsequent to the emission of the volatile organic compounds (VOCs), their atmospheric oxidation results in low-volatility organic compounds that contribute to the condensational growth of particles to sizes which allow them to act as cloud condensation nuclei (CCN) (Riipinen et al., 2012). By including the effects of those $\mathrm{CCN}$ on the radiative balance of the boreal forest in climate models, it has been shown that the previously assumed net positive radiative forcing, due to the low surface albedo (e.g. Bonan, 2008), is counteracted by a more negative cloud albedo radiative forcing, resulting in an overall cooling effect of the boreal forest on the global climate (Spracklen et al., 2008).

Many fundamental aspects of this climate feedback process, like the detailed speciation of emissions, $\mathrm{OH}$-radical budgets, particle formation and aging processes, needed to be investigated in-situ to obtain a more detailed and holistic picture of the ongoing atmospheric processes. In order to clarify these issues, a large comprehensive field campaign (HUMPPA-COPEC 2010) was carried out at the Hyytiälä forest station in southern Finland from 12 July 2010 to 12 August 2010, to investigate summertime conditions in the boreal forest (Williams et al., 2011). Especially the atmospheric oxidation of VOCs and the subsequent secondary organic aerosol (SOA) formation is relevant for improving global climate models, since the major uncertainties are due to the particle-derived direct radiative effect and to the cloud albedo effect (Solomon, 2007). The secondary fraction of organic aerosol (OA) usually makes up the largest proportion of the total aerosol mass (Zhang et al., 2007; Docherty et al., 2008; Jimenez et al., 2009). However, the huge number of different species in the organic fraction, which originates from a variety of different reactive precursors, makes it a considerable analytical challenge to resolve this complexity (Goldstein and Galbally, 2007; Hallquist et al., 2009).

The volatility of an organic compound determines whether the atmospheric processing occurs in the gas or in the particle phase. This is an important factor for global climate models. Since the gas-to-particle partitioning is mass dependent (Pankow, 1994), low-volatility compounds make up a larger fraction of the OA at low mass loadings. In a simplified perspective, the volatility of an organic compound can be regarded as a function of carbon and oxygen atoms (Donahue et al., 2011). Thus, it can be assumed that carboxylic acids make up a significant, if not the most significant, fraction of the particle phase, due to their reduced volatility. Furthermore, quantum mechanical calculations have shown that organic acids in the gas phase can help to surmount the nucleation barrier by forming clusters with sulfuric acid, and thus can play an important role in new particle formation (Zhang, 2010). On the other hand, a large number of organic acids are still volatile enough to partition predominately to the gas phase, where they can be involved in oxidation processes and contribute to the overall gas-phase $\mathrm{OH}$ reactivity. Donahue et al. (2006) argued that the large amount of these intermediate volatile organic compounds (IVOCs), which are present almost entirely in the gas phase (even can contain more mass than the condensed phase), are completely ignored by local and global models.

Recent work illustrated that the $\mathrm{OH}$-initiated aging of semi-volatile organic compounds (SVOCs) and IVOCs in the gas phase is an important part in the formation of SOA (Donahue et al., 2012b) and that the first oxidation step of VOCs is only barely sufficient to form SOA at atmospherically relevant mass concentration levels (Donahue et al., 2012a).

Instruments that provide reliable measurement of single organic species, among the thousands of different compounds in the organic aerosol, are needed in order to investigate those atmospheric processes in detail. In parallel to further improvements of the aerosol mass spectrometer (AMS, Aerodyne, USA) (Jayne et al., 2000; Jimenez et al., 2003; Canagaratna et al., 2007), which operates with hard ionization, recently chemical ionization (CI) has received increasing attention. The advantage of this soft ionization technique is that it preserves the structural information of the molecule (Zahardis et al., 2011; Laskin et al., 2012; Pratt and Prather, 2012). The mass spectrometric separation after ionization can be achieved by various techniques. The most common technique measures the time of flight (ToF) of the ions formed in order to determine their mass-to-charge $(\mathrm{m} / \mathrm{z})$ ratio. Yatavelli et al. (2012) described this technique as highly sensitive (detection limits of organic acids in the particle phase less than $1 \mathrm{ng} \mathrm{m}^{-3}$ ), providing high mass resolution $(R=5000$ above $\mathrm{m} / z, 250)$ and high mass accuracy $( \pm 20 \mathrm{ppm})$. A different mass spectrometric technique is the ion trap mass spectrometry (IT-MS), which typically has less mass resolution and accuracy but offers the unique possibility to distinguish between isobaric species through collisioninduced fragmentation. Isobaric species are ubiquitous in atmospheric aerosols, since the constituents of the main precursor classes of mono- and sesquiterpenes are often isomeric (examples are given in Sect. 3.2).

In this paper the results of the online particle measurements during HUMPPA-COPEC 2010 are presented with special emphasis on biogenic organic acids. Biogenic acids were measured online in the gas and particle phase, with high temporal resolution, by using an atmospheric pressure chemical ionization (APCI) ion trap mass spectrometer (IT-MS) in combination with a mVACES online particle concentrator (Geller et al., 2005; Vogel et al., 2013). These measurements include, to our knowledge, the first in situ $\mathrm{MS}^{2}$ experiments of biogenic acids in the boreal forest. Since the Aerodyne compact time-of-flight aerosol mass spectrometer (C-ToFAMS) was operating simultaneously, we have explored the 
potential of combining soft and hard ionization techniques to gain new insights into aerosol composition and partitioning.

\section{Experimental}

\subsection{Field site description}

From 12 July to 12 August 2010, the large field intensive HUMPPA-COPEC 2010 was carried out at the Station for Measuring Forest Ecosystem-Atmosphere Relations (SMEAR II) at Hyytiälä in Finland. During this period, the continuous long-term on-site measurements were extended by a large suite of instruments for measuring gasand particle-phase chemistry (Williams et al., 2011). The station is located in southern Finland $\left(61^{\circ} 51^{\prime} \mathrm{N}, 24^{\circ} 17^{\prime} \mathrm{E}\right.$, $181 \mathrm{~m}$ a.s.l.) in the middle of a $\sim 50 \mathrm{yr}$ old Scots pine ( $\mathrm{Pi}$ nus sylvestris $\mathrm{L}$.) stand, with homogenous Scots pine forest forming also the main larger-scale surroundings, thus representing well the boreal coniferous forest environment (Hari and Kulmala, 2005; Kulmala et al., 2001). The town nearest to SMEAR II, Orivesi (10000 inhabitants), is situated $15 \mathrm{~km}$ south of the station, and the city of Tampere (215000 inhabitants) is located approximately $50 \mathrm{~km} \mathrm{SW}$ from the station. The city of Helsinki lies $200 \mathrm{~km}$ to the south of the station and St. Petersburg approximately $350 \mathrm{~km}$ south-east.

\subsection{Field campaign instrumentation}

\subsubsection{Online aerosol mass spectrometry}

Two online and collocated (same inlet) aerosol mass spectrometers were measuring simultaneously in the main SMEAR II cottage for detailed online chemical analysis of non-refractory submicron particles: (1) an atmospheric pressure chemical ionization ion trap mass spectrometer (APCI-IT-MS, Finnigan LCQ; Hoffmann et al., 2002, Kückelmann et al., 2000) in conjunction with a miniature versatile aerosol concentration enrichment system (mVACES; Geller et al., 2005) as described by Vogel et al. (2013) and (2) the Aerodyne C-ToF-AMS (Drewnick et al., 2005). Filter samples for FTIR analysis were taken at a distance of approximately $200 \mathrm{~m}$ from the main cottage.

Briefly, the APCI-IT-MS produces primary ions by corona discharge at atmospheric pressure. In the negative ion mode, gaseous compounds having a higher gas-phase acidity become ionized by proton transfer reaction with $\mathrm{O}_{2}^{-}$ions, and are then mass analyzed by the quadrupole ion trap. Prior to the discharge region source, particulate compounds become vaporized by a heating unit. The measurable compound classes are mainly restricted to organic molecules including a carboxylic functional group (organic acids), sulphate and organic molecules with a sulphate group (e.g. organosulfates). The class of nitrophenols can be detected in the negative mode as well. Organic compounds, which show fast thermal decomposition, were measured with a much lower sensitiv- ity than other biogenic acids. The spectrum was recorded between $m / z 50$ to 500, and one recorded spectrum per minute was averaged from 200 microscans.

The aerosol mass spectrometer (Aerodyne Research Inc., Billerca, MA, USA) is an instrument capable of directly measuring the chemical composition of aerosols using time-offlight mass spectrometry. The AMS is widely used and its operation principle and data analysis methods have been described in detail elsewhere (Canagaratna et al. (2007), general information on AMS; Drewnick et al. (2005), a description of the C-ToF-AMS variant used in this study). Analysis of the AMS data has been described by e.g. Allan et al. (2003, 2004), and the analysis procedure during HUMPPA-COPEC 2010 and the general AMS data outlook during the campaign by Vogel et al. (2013).

In short, the AMS uses an aerodynamic lens to form the sample aerosol into a particle beam. This beam is then modulated by a beam chopper and directed to a particle timeof-flight (PToF) chamber for size distribution measurement. After the PToF chamber, the sample aerosol is thermally vaporized, resulting in the non-refractory aerosol particle components (i.e. those vaporizing in 600 degrees Celsius or less) transforming to gas phase in the ionization region. The gaseous molecules are subsequently ionized via $70 \mathrm{eV}$ electron ionization, forming both positive and negative ions. The positive polarity ions are selected and led to the time-of-flight mass analyzer. The analysis happens in real time, and sample is continuously collected via the inlet, while the inside of the instrument is kept under high vacuum by a differential pumping system consisting of five turbomolecular pumps.

The time-of-flight data from the mass analyzer are inverted to yield $m / z$ mass spectra, based on which the observed signal amounts are assigned to various chemical species. Using calibration data, the amount of signal is then quantified to give out particle mass concentrations in micrograms per cubic metre for organic compounds, sulfates, nitrates, ammonia compounds and chlorides.

\subsubsection{Offline FTIR filter measurements}

Submicron particles were collected $4 \mathrm{~m}$ above ground level on $37 \mathrm{~mm}$ Teflon filters (Pall Inc., $37 \mathrm{~mm}$ diameter, $1.0 \mu \mathrm{m}$ pore size Teflon membrane), downstream of a $1 \mu \mathrm{m}$ sharp-cut cyclone (SCC 2.229 PM1, BGI, Inc.) (Corrigan et al., 2013). The aerosol was dried to less than approximately $75 \% \mathrm{RH}$ prior to reaching the cyclone. Filter collection times varied at 6,9 , and $12 \mathrm{~h}$, including duplicate $24 \mathrm{~h}$ filters, and were based on real-time OM values measured by the C-ToF-AMS in order to maximize resolution time while staying above the detection limit. After collection, the filters were stored at $0^{\circ} \mathrm{C}$ before they were analyzed in San Diego, California, by a Tensor 27 spectrometer with a DTGS detector (Bruker, Billerica, MA). A peak-fitting algorithm described in Russell et al. (2009) and Takahama et al. (2013) was used to quantify organic functional groups from the FTIR spectra. Quantified 
organic functional groups included alcohol, alkane, carboxcylic acid, primary amine and non-acid carbonyl. Alkene and aromatic functional groups were below the limit of quantification during the sampling period.

\subsubsection{Black carbon Aethalometer}

Black carbon is not detected by the AMS, as it is not vaporized at $600^{\circ} \mathrm{C}$. Therefore, a separate instrument was needed to obtain black carbon (BC) mass during the campaign. For this purpose the SMEAR II site Aaethalometer (Magee Scientific Corporation, Berkeley, CA 94704, USA) data were used. The instrument measures light absorption of an aerosol collector tape, at several wavelengths, to determine the mass concentration of black carbon particles. Together the AMS data on non-refractory particles and the $\mathrm{BC}$ data from the Aethalometer form a comprehensive picture of the Hyytiälä submicron aerosol basic chemical composition.

\subsection{Other}

\subsubsection{Laboratory experiments}

In a $100 \mathrm{~L}$ dark continuous-flow reaction chamber (glass and Teflon), $\sim 200 \mathrm{ppb}$ of (+)- $\alpha$-pinene (Sigma-Aldrich, $\geq 99 \%$ ) and (+)-3-carene (Fluka analytical, $\geq 98.5 \%$ ), vaporized in an external thermal diffusion source, were mixed with approximately $1 \mathrm{ppm}$ of ozone (1008-RS, Dasibi Environmental Corp., Glendale, CA, USA) to produce secondary organic aerosol. The aerosol from this chamber was sampled directly through an activated charcoal denuder (length $\sim 0.5 \mathrm{~m}$, ID $\sim 0.5 \mathrm{~cm}$ ) into the ion source of the APCI-IT-MS in order to record the online mass spectra.

To record the $\mathrm{MS}^{2}$ spectra of selected authentic standards, vanillic acid (Sigma-Aldrich, $\geq 97 \%$ ), cis-pinonic acid (Sigma-Aldrich, $98 \%$ ) and self-synthesized pinic acid were dissolved as $0.1 \mathrm{mM}$ aqueous solutions. Out of these solutions a polydisperse aerosol was generated using a TSI 3076 atomizer. Before entering the APCI ion source, the aerosol was dried using a silica diffusion dryer. Due to the lack of a standard of 3-methyl-1,2,3-butanetricarboxylic acid, the MS ${ }^{2}$ spectrum of this compound was recorded using (-)ESI-UHR-MS after LC separation of an ambient filter sample extract, collected at the Taunus Observatory, Germany.

\subsubsection{Trajectory analysis}

Backward trajectories were obtained from the web-based HYSPLIT model (HYbrid Single-Particle Lagrangian Integrated Trajectory; Draxler and Rolph, 2013), which can be accessed on the NOAA Air Resources Laboratory website (http://ready.arl.noaa.gov) (Rolph, 2013). The length of the backward calculation was set to $96 \mathrm{~h}$ and the arrival height at $25 \mathrm{~m}$ above ground level.

\section{Results and discussion}

\subsection{Aerosol chemical variation and source apportionment during HUMPPA-COPEC 2010}

Figure 1 displays the temporal pattern of three different particle-phase measuring techniques during the HUMPPACOPEC 2010 campaign. The blue time series in the top panel represents the total counts of organic acids (and possibly other compound classes such as organosulfates or nitrophenols and -catechols) in the particle phase, which is the sum of the signal intensities between $m / z, 150$ and $m / z$ 500, measured by APCI-IT-MS. The green time series shows OA measured by the AMS, which ranged from below detection limit (day 204) to $23 \mu \mathrm{g} \mathrm{m}^{-3}$ (day 210). As can be seen, AMS organics and APCI-IT-MS show a similar pattern throughout the campaign, both capturing days 207-211 with the highest aerosol concentrations.

In the middle panel of Fig. 1, a PMF (positive matrix factorization; see e.g. Paatero and Tapper, 1994) solution for the AMS measurements is shown, using the solutions from Corrigan et al. (2013). The PMF analysis is one way to deconvolve the complex AMS mass spectra to yield source-specific time series and mass spectra for the different organic aerosol types. From the PMF solution space, a solution of three factors (FPEAK $=-0.4$ ) was selected, as in this solution a very clear high $\mathrm{f} 43$ factor (OOA-2) emerges. The FPEAK selection was based on obtaining the clearest difference in correlation profiles for the factors and auxiliary measurements (i.e. trace gases, BC, and AMS inorganics). However, the two other obtained high f44 factors had similar temporal behaviour, mass spectra and correlation profiles with auxiliary measurements, and they were thus combined to form the OOA-1 factor in this analysis. A probable interpretation for the three-factor solution would be that the organic aerosol is divided into (1) long-range transported anthropogenic pollution (OOA-2) and (2) highly oxidized BBOA generated from Russian wildfires, and highly oxidized biogenic-related OA (OOA-1). In order to avoid possible over-interpretation of the highly aged aerosol, only the OOA-2 factor and the (combined) OOA-1 factor are presented (the mass spectra can be found in the Supplement).

The lowermost time series represents the different organic functional groups (alcohol, alkane, non-acid carbonyl, amine and carboxylic acid), which were determined by filter-based measurements using FTIR.

Total submicron OM measured by FTIR (lower panel) varied substantially throughout the campaign, with an average of $4.3 \pm 3.9 \mu \mathrm{g} \mathrm{m}^{-3}$. The highest OM concentrations, $23 \mu \mathrm{g} \mathrm{m}^{-3}$, were observed with the arrival of aged biomass burning emissions from central Russia on day 221 . The lowest OM concentrations, roughly $0.4 \mu \mathrm{g} \mathrm{m}^{-3}$, were measured on day 204 and 205, when air masses arrived from northern Scandinavia and the Arctic Ocean. The organic functional group composition was dominated by oxygenated groups, 

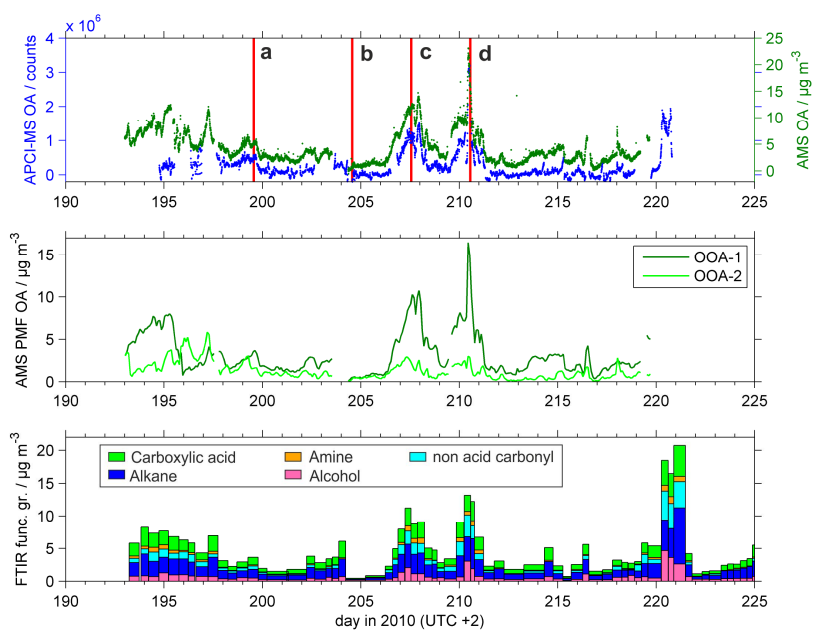

Fig. 1. Temporal variation of organic aerosol during HUMPPACOPEC 2010. Top panel: summation of particle-phase signals between $\mathrm{m} / z \quad 150$ and 500 measured by APCI-IT-MS (blue) vs. the total submicron organic mass concentration measured by AMS (green). Middle panel: two-factor PMF analysis of AMS data (OOA: oxygenated organic aerosol, factor OOA-1 and OOA-2; see text). Lower panel: mass concentration of functional groups measured by filter-FTIR.

carboxylic acid (28\%), non-acid carbonyl (15\%), and alcohol $(15 \%)$ groups, consistent with the high $\mathrm{O} / \mathrm{C}$ measured by the AMS. Despite the fluctuation in total OM, the fraction of oxygenated organic functional groups remained frequently constant throughout the campaign.

The temporal resolution of the online measurements of the APCI-IT-MS and the AMS are 5 min averages, AMS-PMF data are based on $30 \mathrm{~min}$ average intervals, and the average filter sampling time for FTIR analysis is approximately $9 \mathrm{~h}$.

The red marked periods (a-d) in the top panel are $3 \mathrm{~h}$ intervals - the respective average APCI-IT-MS gas- and particlephase mass spectra and the average chemical composition measured by AMS are shown in Fig. 2. These intervals were chosen to illustrate how mass spectra of the gas and particle phase vary with different air mass histories. All four spectra are averaged between 12:00 and 15:00 LT (UTC +2) of the respective day.

During (a) (day 199, 18 July 2010, 12:00-15:00 UTC+2), the back trajectory analysis (Fig. 3) indicates that the air masses arriving at the site were coming from the SW, descending from higher altitudes over Sweden and the Baltic Sea. Average submicron particulate mass (PM) during this period was $7.2 \mu \mathrm{g} \mathrm{m}^{-3}$. The organic acid distribution in the particle phase shows a bimodal distribution with maxima around $m / z 200$ and $m / z$ 300, respectively. The maximum at lower $m / z$ ratios can be explained by the contribution of monoterpene-derived organic acids, which are mainly measured in the range below $m / z 230$. We assume that the higher molecular weight compounds can be attributed to sesquiter-

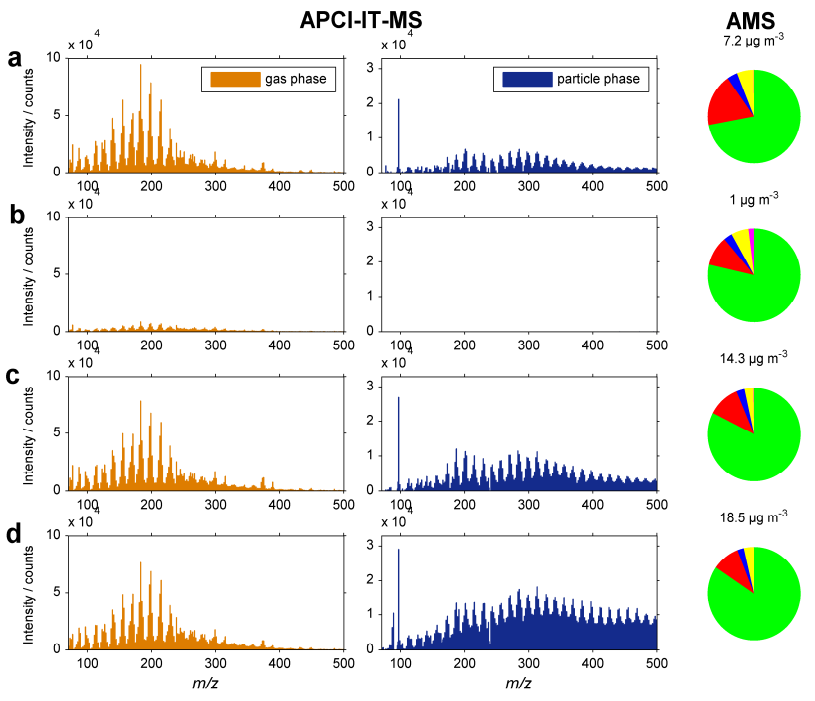

Fig. 2. Average composition of the gas and particle phase on four different days during HUMPPA-COPEC 2010 (Fig. 1a-d) measured by APCI-IT-MS and AMS. Black carbon is not included in the AMS pie charts but in the numbered submicron mass concentration.

pene oxidation products, aged oligomers of low molecular compounds (isoprene, glyoxal), dimers of monoterpene oxidation products or, most probably, a combination of these precursors. The $m / z$ distribution in the gas phase has its maximum on $m / z$ 183. Generally, the gas-phase spectrum during (a), (c) and (d) are very equally distributed. The small signals in the $m / z$ 370-390 area are most probably cluster artefacts of smaller organic acids (e.g. 2-hydroxyterpenylic acid), as was described by Claeys et al. (2009). Although the air masses during (a) were coming from SW and might be influenced by Helsinki and Tampere pollution, the CO mixing ratio during this period was $103.8 \mathrm{ppbV}$, distinctly below the mean campaign CO mixing ratio of $208.5 \mathrm{ppbV}$. This suggests that the air masses are only marginally influenced by anthropogenic activities or biomass burning.

On day 204 (b) (23 July 2010, 08:00-13:00 UTC+2), the sole new particle formation (NPF) event during the campaign occurred. In general, during summertime, NPF occurs quite rarely: annual variation of NPF peaks in spring and autumn (Dal Maso et al., 2007). Back trajectory analysis of this day shows that air masses were coming from the Arctic region at high altitudes, descending over the Gulf of Bothnia and then residing approximately $12 \mathrm{~h}$ over the Finnish boreal forest before arriving at the Hyytiälä station. Hence, clean air masses coming from the Arctic region are favourable for NPF events during summertime, since the low number of pre-existing aerosol particles does not provide sufficient surface for condensation of low-volatility species. This agrees with the observation made by Nilsson et al. (2001), who described a prevalence for NPF occurring in clean Arctic air masses. Such cold air outbreaks from the Arctic region form 


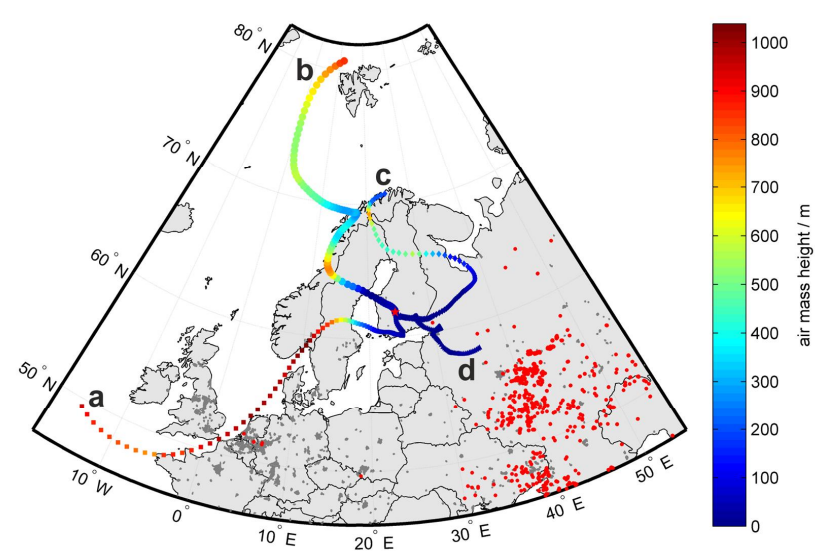

Fig. 3. $96 \mathrm{~h}$ backward trajectory analysis of four different days (ad) using the NOAA HYSPLIT model. (a) to (d) refer to the average intervals in Fig. 1 (arrival time 14:00 LT (UTC+2) of the respective day). The red star marks the SMEAR station at Hyytiälä. MODIS fire data are $100 \%$ CI fire spots between 18 July 2010 and 29 July 2010. Land, borders and populated areas are based on Natural Earth shapefiles (http://www.naturalearthdata.com).

rarely during summer time. The average submicron particlephase concentration on 23 July 2010, 12:00-15:00 LT, was $0.97 \mathrm{~g} \mathrm{~m}^{-3}$, and the nucleation event started in the morning hours. The average $\mathrm{CO}$ mixing ratio was $78.2 \mathrm{ppbV}$ - close to the minimum $\mathrm{CO}$ mixing ratio $(77.5 \mathrm{ppbV})$ of the campaign, which was measured in the morning hours of the same day. The average APCI-IT-MS gas-phase spectrum shows a very weak signal of organic acids, e.g. on $m / z 1838700$ counts the campaign average on $m / z 183$ was 72000 counts. Thus, the signal measured during (b) is only slightly above the instrumental background ( $\sim 6700$ counts, $3 \times$ standard deviation (SD) of the noise signal). The particle-phase signals during the NPF event are below detection limit, indicating the analytical limitations of the utilized setup.

Back trajectory analysis of day 207 (c) (26 July 2010) indicates that air masses were coming from NE situated at low altitudes for approximately $72 \mathrm{~h}$ before arriving at the Hyytiälä station. Elevated CO levels (188.7 ppbV) are a hint for biomass burning influence and/or anthropogenic pollution from the St. Petersburg region. Average PM1 was $14.3 \mu \mathrm{g} \mathrm{m}^{-3}$ and the average mass loading of sulphates $1.6 \mu \mathrm{g} \mathrm{m}^{-3}$, both unusually high for the SMEAR II station. A bimodal distribution with two maxima at $\sim m / z$ 180-190 and $m / z$ 280-290 appears in spectrum (c), slightly shifted towards lower $m / z$ ratios compared to spectrum (a).

Comparing the particle-phase spectra (c) and (d) reveals that higher molecular compounds account for a higher proportion of the total aerosol mass in (d) than in (c). The average spectrum in (d) was measured during day 210 - a period of strong influence from the central Russia biomass burning events in the Nizhny Novgorod region (Konovalov et al., 2011; Portin et al., 2012). During this time (day 210, 29 July
2010) the highest aerosol mass was measured $\left(27.1 \mu \mathrm{g} \mathrm{m}^{-3}\right.$ (non-refractory aerosol, AMS), $1.9 \mu \mathrm{g} \mathrm{m}^{-3}$ black carbon (Aethalometer)), accompanied by the highest temperature $\left(32.6^{\circ} \mathrm{C}\right)$, lowest visibility and highest $\mathrm{CO}$ mixing ratio (437.7 ppbV). PMF analysis shows the highest fraction of $\mathrm{f} 44$ (OOA-1). As has been shown by Vogel et al. (2013), during this time the estimated sum of organic acids contributes more than the campaign average to the total OA mass. The O/C ratio measured by FTIR, which can be regarded as a proxy for the aerosol oxidation state, was 0.70 on this day, and thus above the average $\mathrm{O} / \mathrm{C}$ ratio of the campaign $(\mathrm{O} / \mathrm{C}=0.56)$. A similar aerosol oxidation proxy for the AMS data, the ratio of signals in $m / z 44$ to $m / z 43$, also averages relatively high at 3.10 for the day in question, compared to a campaign average of 2.34. Due to the strong influence of the biomass burning, it is highly probable that the aerosol contains significant amounts of compounds which are, under normal conditions, not present in boreal forest aerosol. However, the high contribution of organic acids can be explained by the prolonged period of photochemical aging experienced by the plume before arriving at the station. The back trajectories suggest that the emitted aerosol from central Russia spent more than three days at low altitudes before arriving at Hyytiälä without encountering wet deposition. During this time, biomass burning markers, like levoglucosan and other lignin-derived organic compounds, can undergo strong heterogeneous oxidation and become volatilized, oligomerized or functionalized (Kroll et al., 2011). Functionalized (e.g. carboxylic acid functionalities) compounds can then be detected in the negative ionization mode of the APCI-IT-MS. Gas-phase oxidation of additionally released VOCs through biomass burning (Andreae and Merlet, 2001) and subsequent gas-to-particle conversion increases the aerosol mass as the plume is transported to the SMEAR station. Kessler et al. (2010) illustrated the significant volatilization during the oxidation of levoglucosan. In contrast to levoglucosan, organic acids show little mass volatilization during heterogeneous $\mathrm{OH}$ oxidation, since the loss of carbon is roughly equivalent to the increase of oxygen (Kessler et al., 2012). Therefore it can be concluded that the proportion of organic acids in biomass burning aerosol increases during aging not only due to gas-phase and heterogeneous oxidation but also due to the oxidative volatilization of non-acidic compounds in the aerosol phase. Lastly, it should be noted that the high temperature and the biomass burning events during the summer 2010 can be regarded as an extreme anomaly, compared to average boreal forest summer conditions (see Williams et al., 2011).

\subsection{Monoterpene oxidation products during HUMPPA- COPEC 2010 compared to simulation chamber ozonolysis of $\alpha$-pinene and $\Delta^{3}$-carene}

Detailed knowledge of the specific VOC emission pattern of the boreal forest helps to understand the chemistry and the composition of the boreal forest aerosol. Therefore 

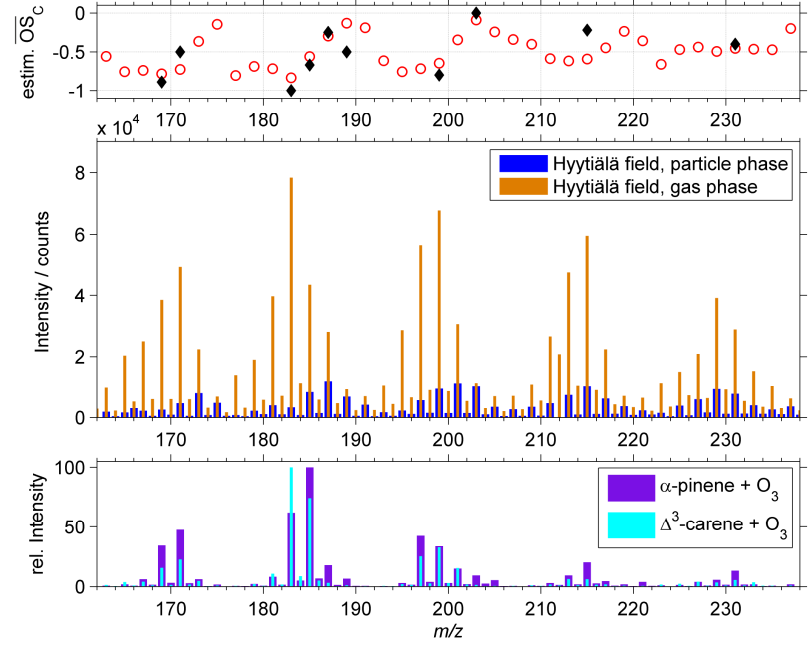

Fig. 4. Top panel: estimated average oxidation states (red circles) derived from oxidation states of literature terpenoid organic acids (black diamonds; see Table 1). Middle panel: average spectrum of organic acids in the ambient air measured with APCI-IT-MS in the negative mode on day 207 (26 July 2010, 12:00-15:00 LT $(\mathrm{UTC}+2)$ ). Bottom panel: average spectrum of laboratory dark ozonolysis experiments with $\alpha$-pinene and $\Delta^{3}$-carene.

measurements of ambient VOC mixing ratios, using adsorptive preconcentration followed by thermal desorptiongas chromatography-mass spectrometry (TD-GC-MS), were carried out during the HUMPPA-COPEC 2010 campaign. Those measurements showed that the mixing ratios of the most abundant biogenic compounds ( $\alpha$-pinene, $\Delta^{3}$-carene and $\beta$-pinene) in ambient air ranged between a few pptV and 1.5 ppbV (Yassaa et al., 2012).

Additionally, laboratory $\alpha$-pinene and $\Delta^{3}$-carene dark ozonolysis experiments were conducted in the laboratory for comparison with the ambient APCI-IT-MS data. The ambient spectrum and the laboratory spectrum shown in Fig. 4 focus on the range between $\mathrm{m} / z 160$ and $\mathrm{m} / \mathrm{z} 240$, which includes the most important terpenoid acids. Although there is a certain amount of $\mathrm{OH}$ radicals which are formed during the terpene ozonolysis, a recent study by Hall et al. (2013) shows that the additional oxidation of $\alpha$-pinene ozonolysis products by $\mathrm{OH}$ radicals leads to the fragmentation of the dimeric products and an overall increase of the oxidation state. Therefore we like to mention that the different oxidative environment between laboratory and ambient air might result in different products which cannot be distinguished by the used method.

The ambient data are a three-hour average of 26 July 2010 , 12:00-15:00 LT (UTC+2). The partitioning of specific compounds between gas and particle phase during the campaign will be discussed in chapter 3.5 - this chapter focuses on the discussion of the chemical composition.
Three main conclusions can be drawn from the pattern of the ambient mass spectra (Fig. 4, middle panel):

1. The regular pattern of $\Delta \mathrm{m} / z 14$ between the major signals in the particle phase can be attributed to an increasing number of $\mathrm{CH}_{2}$ groups in the carbon backbone. The gas phase does not show this $\Delta m / z 14$ pattern as clearly as the particle phase.

2. The low signals on even $m / z$ ratios can be attributed to ${ }^{13} \mathrm{C}$-containing molecules since the pattern follows the odd $\mathrm{m} / \mathrm{z}$ pattern and ratios to the monoisotopic ion are within the expected intensity distribution. However, the presence of nitrogen-containing organic acids cannot be ruled out since the instrumental ionization method might suppress compounds with a higher gasphase basicity.

3. By comparing the gas- and particle-phase signal distribution in one peak cluster (e.g. from $m / z 176$ to $m / z$ 192), it becomes obvious that the maximum particle-phase signals are shifted towards higher masses.

The last observation can be explained by a different average carbon oxidation $\left(\overline{\mathrm{OS}}_{\mathrm{C}}\right)$ state of the respective compounds in one peak cluster, meaning that the maximum gas-phase compounds (e.g. all compounds on $m / z$ 183) are on average less oxidized than the maximum particle-phase compounds (e.g. all compounds on $m / z$ 187). Since $\overline{\mathrm{OS}}_{\mathrm{C}}$ is strongly related to volatility, an approach to determine $\overline{\mathrm{OS}}_{\mathrm{C}}$ from the measured ratio between the particle- and the gas-phase signal (Supplement) resulted in values between -1 and 0 (Fig. 4, top panel). A clear repetitive character of an increasing oxidation state in the three peak clusters $<m / z 206$ can be seen. As has recently been shown by ESI-UHR-MS of filter samples from Hyytiälä, $\overline{\mathrm{OS}}_{\mathrm{C}}$ values of single compounds in ambient aerosol from Hyytiälä fall in the range between -1 and 1 (Kourtchev et al., 2013). To which extent highly oxidized compounds $(>0)$ contribute to the total aerosol mass and how those compounds are formed needs to be investigated in future measurements.

Comparison between the ambient gas-phase spectrum (middle panel, Fig. 4) and the $\Delta^{3}$-carene- and $\alpha$-pineneozonolysis spectrum (bottom panel, Fig. 4) shows the same number of peak clusters and that the peak cluster in the $\mathrm{m} / \mathrm{z}$ 180 to 190 region is the most dominant one. The spectral pattern of both monoterpene precursors in the laboratory $\left(\Delta^{3}-\right.$ carene- and $\alpha$-pinene) are similarly distributed, which can be explained by the fact that ozonolysis of different monoterpenes results in a highly similar product distribution (Glasius et al., 2000). Furthermore, it can be seen that the ambient gas-phase spectrum is more similar to the chamber spectrum than the ambient particle-phase spectrum. This is most probably because the aerosol in the chamber does not undergo the same degree of heterogeneous aging as the ambient aerosol. 
Table 1. Considered literature organic acids for the estimation of $\overline{\mathrm{OS}}_{\mathrm{C}}$.

\begin{tabular}{llcccl}
\hline Compound & Elem. comp. & $m / z\left([\mathrm{M}-\mathrm{H}]^{-}\right)$ & $\overline{\mathrm{OS}}_{\mathrm{C}}{ }^{\mathrm{a}}$ & PP/GP & Reference \\
\hline Norpinonic acid & $\mathrm{C}_{9} \mathrm{H}_{14} \mathrm{O}_{3}$ & 169 & -0.89 & $6.6 \times 10^{-2}$ & Yu et al. (1998) \\
Norpinic acid & $\mathrm{C}_{8} \mathrm{H}_{12} \mathrm{O}_{4}$ & 171 & -0.50 & $9.4 \times 10^{-2}$ & Hoffmann et al. (1998) \\
Pinonic acid & $\mathrm{C}_{10} \mathrm{H}_{16} \mathrm{O}_{3}$ & 183 & -1.00 & $4.2 \times 10^{-2}$ & Yu et al. (1998) \\
Pinic acid & $\mathrm{C}_{9} \mathrm{H}_{14} \mathrm{O}_{4}$ & 185 & -0.67 & $1.9 \times 10^{-1}$ & Yu et al. (1998) \\
2-hydroxyterpenylic acid & $\mathrm{C}_{8} \mathrm{H}_{12} \mathrm{O}_{5}$ & 187 & -0.25 & $4.3 \times 10^{-1}$ & Claeys et al. (2009) \\
Diaterpenylic acid & $\mathrm{C}_{8} \mathrm{H}_{14} \mathrm{O}_{5}$ & 189 & -0.50 & $7.4 \times 10^{-1}$ & Yasmeen et al. (2012) \\
10-hydroxypinonic acid & $\mathrm{C}_{10} \mathrm{H}_{16} \mathrm{O}_{4}$ & 199 & -0.80 & $1.4 \times 10^{-1}$ & Glasius et al. (1999) \\
MBTCA & $\mathrm{C}_{8} \mathrm{H}_{12} \mathrm{O}_{6}$ & 203 & 0.00 & $8.8 \times 10^{-1}$ & Szmigielski et al. (2007) \\
Diaterebic acid acetate & $\mathrm{C}_{9} \mathrm{H}_{14} \mathrm{O}_{6}$ & 217 & -0.22 & $1.7 \times 10^{-1}$ & Iinuma et al. (2009) \\
Diaterpenylic acid acetate & $\mathrm{C}_{10} \mathrm{H}_{16} \mathrm{O}_{6}$ & 231 & -0.40 & $2.7 \times 10^{-1}$ & Claeys et al. (2009) \\
\hline
\end{tabular}

\footnotetext{
${ }^{\text {a After }} \overline{\mathrm{OS}}_{\mathrm{C}} \approx 2 O / \mathrm{C}-\mathrm{H} / \mathrm{C}$ (Kroll et al., 2011).

b PP: particle phase; GP: gas phase; average signal measured during day 207 (26 July 2010, 12:00-15:00 LT (UTC+2)) (see Supplement for estimation of average oxidation state of unattributed $m / z$ ratios).
}

Although the spectra comparison might suggest that single species cause one $m / z$ signal, the main signals in the spectra cannot be attributed unambiguously to one certain compound. This is due to the possible presence of isobaric compounds, and thus we cannot state with certainty how much one compound contributes to one $m / z$ signal. To give a concrete example: regarding only $\alpha$-pinene oxidation, several different compounds are formed which have the same molecular weight; e.g. the signal on $\mathrm{m} / z 185$ can be assigned to cis-pinic acid $\left(\mathrm{C}_{9} \mathrm{H}_{14} \mathrm{O}_{4}\right)$. Cis-pinic acid is a main oxidation product of $\alpha$-pinene and $\beta$-pinene (Hoffmann et al., 1998; Yu et al., 1999; Glasius et al., 1999). In addition, other isobaric organic acids like hydroxynorpinonic acids and 4hydroxypinalic-3-acid, formed in the $\alpha$-pinene/ozone reaction, can contribute to the signal $m / z 185$ as well (Yu et al., 1999; Jaoui and Kamens, 2003).

Other mono- and sesquiterpene precursors form isobaric products, all consisting of $\mathrm{C}_{9} \mathrm{H}_{14} \mathrm{O}_{4}$ as well, and thus contributing to the $m / z 185$ signal:

1. $\Delta^{3}$-carene forms 3-caric acid and $\mathrm{OH}-3$-caralic acid (Yu et al., 1998; Ma et al., 2009);

2. limonene forms ketolimononic acid and limonic acid (Jaoui et al., 2006; Gomez-Gonzalez et al., 2012);

3. sabinene forms sabinic acid and hydroxy norsabinonic acid (Yu et al., 1999);

4. myrtenol forms 9-hydroxynorpinonic acid (Glasius et al., 1999);

5. $\beta$-pinene forms homoterpenylic acid (Yasmeen et al., 2010);

6. $\beta$-caryophyllene forms 2-(carboxymethyl)-3,3dimethylcyclobutanecarboxylic acid (Alfarra et al., 2012).
In total this results in twelve possible isobaric species in SOA with the elemental composition of $\mathrm{C}_{9} \mathrm{H}_{14} \mathrm{O}_{4}$, an indication of the complexity of the organic fraction of atmospheric aerosols even under relatively well defined boreal conditions with minor anthropogenic influences.

Furthermore, due to the unit mass resolution of the instrument used, it cannot be ruled out that other non-isomeric compounds contribute to the $m / z 185$ signal as well, e.g. undecanoic acid $\left(\mathrm{C}_{11} \mathrm{H}_{22} \mathrm{O}_{2}\right)$, or organic acids with the elemental composition of e.g. $\mathrm{C}_{10} \mathrm{H}_{18} \mathrm{O}_{3}$ or $\mathrm{C}_{8} \mathrm{H}_{10} \mathrm{O}_{5}$. However, Warnke et al. (2006) showed by HPLC-(-)ESI-MS of filter samples from Hyytiälä that 3-caric acid and cis-pinic acid are the most abundant organic acids on $m / z 185$ in the particle phase of the boreal forest aerosol, which is in agreement with the previous assumption that $\alpha$-pinene and $\Delta^{3}$-carene are the major monoterpenoic precursors at Hyytiälä.

Despite the similarity between ambient and laboratory SOA, some minor signals only appear in the ambient spectrum, e.g. $m / z 177, m / z 191, m / z 193, m / z$ 207. To our knowledge organic acids of these molecular masses have neither been found in ambient filter samples nor been predicted by chemical mechanism models. Either these signals are real, emerging from unstable compounds, which cannot be captured by filter measurements, or these signals are fragmentation or cluster artifacts generated during the online ionization process.

The ambient particle-phase spectrum in Fig. 4 (middle panel, blue bars) shows the strongest signals on $m / z 173$, $m / z 187, m / z 201, m / z 215$ and $m / z 229-$ a the regular pattern of $\Delta m / z 14$ occurs. In the following discussion we want to focus on $m / z$ 187, $m / z 203$ and $m / z$ 231, since compounds with a molecular weight related to these $m / z$ ratios have been described in the literature. As mentioned above, the higher partitioning of $m / z 187$ and $m / z 203$ to the particle phase when compared to $m / z 183$ and $m / z 199$ can be explained by a higher oxidation state. Compared to the rapid 
formation of first-generation acids $(m / z$ 183, e.g. cis-pinonic acid) in chamber experiments, further atmospheric oxidation towards higher oxidized compounds takes minutes to hours. This is the reason why higher oxidized compounds are not observed in the SOA chamber spectrum as being as strong as in the ambient spectrum.

Claeys et al. (2009) reported the measurement of 2hydroxyterpenylic acid (MW 188, $\mathrm{C}_{8} \mathrm{H}_{12} \mathrm{O}_{5}$ ), which was present in ambient $\mathrm{PM}_{2.5}$ filter samples from a mixed coniferous/deciduous forest $12 \mathrm{~km} \mathrm{NE}$ of Antwerp, Belgium. Since this compound is not very abundant in chambergenerated $\alpha$-pinene SOA, Claeys et al. (2009) suggested that it is formed via oxidation of the first-generation terpenylic acid. The high signal in the particle phase at $\mathrm{m} / z$, 187 might suggest that the compounds contributing to this signal are less volatile than e.g. the dicarboxylic acid cis-pinic acid $(m / z$ 185). However, 2-hydroxyterpenylic acid is most probably more volatile than cis-pinic acid as it possesses one carbon atom and one carboxylic acid group less. Another identified carboxylic acid that would appear at $\mathrm{m} / z$. 187 is ketolimonic acid $\left(\mathrm{C}_{8} \mathrm{H}_{12} \mathrm{O}_{5}\right)$, which consists also of one carbon atom less than cis-pinic acid, but which contains two carboxylic acid functional groups and one keto function (Jaoui et al., 2006; Rossignol et al., 2012). Thus, ketolimonic acid is approximately one order of magnitude less volatile than cispinic acid and therefore might reasonably explain the high signal of $m / z, 187$ in the particle phase. Furthermore, Yasmeen et al. (2011) suggested hydroxylated norpinic acid as a possible compound at $m / z$ 187; however, unambiguous identification has not been made so far.

The signal $\mathrm{m} / \mathrm{z}, 203$ can tentatively be assigned to the compound 3-methyl-1,2,3-butanetricarboxylic acid $\left(\mathrm{C}_{8} \mathrm{H}_{12} \mathrm{O}_{6}\right.$, MBTCA), which forms during aerosol aging by gasphase OH-radical-induced oxidation of cis-pinonic acid (Szmigielski et al., 2007; Müller et al., 2012). Kourtchev et al. (2008) measured MBTCA concentrations based on filter sampling/LC-MS measurements in the range from 1.6 to $99.3 \mathrm{ng} \mathrm{m}^{-3}$. The maximum value of $\mathrm{m} / z 203$ during the HUMPPA-COPEC campaign was measured on day 210. This confirms that MBTCA can be regarded as an aerosol aging marker for biogenic SOA, since the back trajectory on day 210 indicates several days of intensive photochemical aging over the boreal forest. MBTCA has a high $\mathrm{O} / \mathrm{C}$ ratio $(0.75)$ and is expected to partition almost completely to the particle phase. Nevertheless, a significant amount of $m / z 203$ was measured in the gas phase. Possible explanations for this observation are isobaric interference of other more volatile organic compounds (see Sect. 3.3) and a biased partitioning due to an amorphous aerosol phase state (see Sect. 3.5).

In chamber studies of $\alpha$-pinene and limonene ozonolysis, the signal $\mathrm{m} / z, 231$ has been described by Warscheid and Hoffmann (2002), who suggest several highly oxidized products with the composition of $\mathrm{C}_{10} \mathrm{H}_{16} \mathrm{O}_{6}$. Claeys et al. (2009) propose diaterpenylic acid acetate as a SOA tracer for $\alpha$ pinene photooxidation, which has been measured in daytime

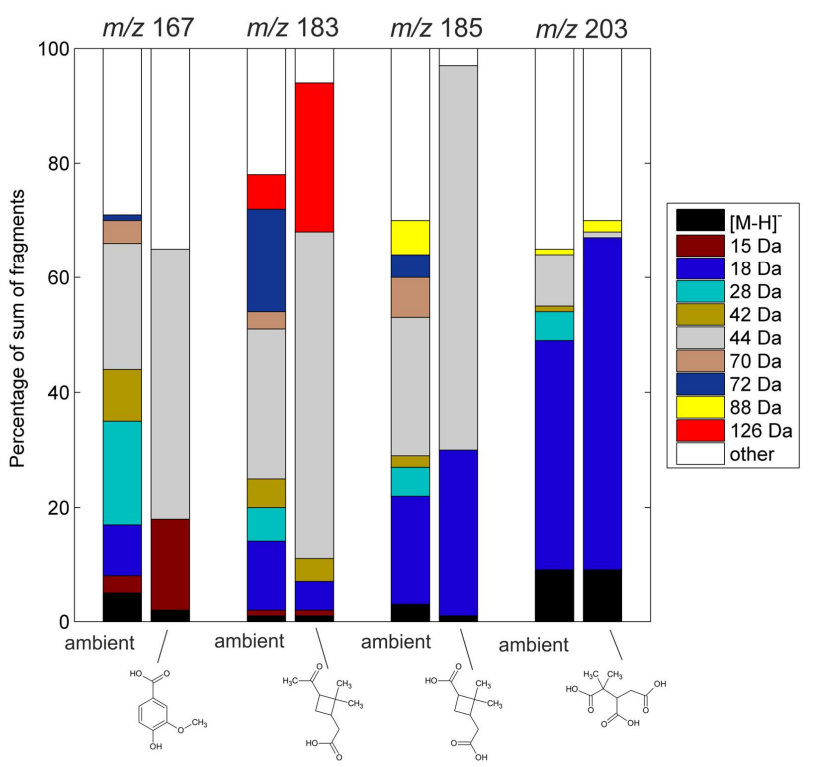

Fig. 5. Neutral losses of four distinct $\mathrm{m} / \mathrm{z}$ ratios during online $\mathrm{MS}^{2}$ on 22 July 2010, 13:20-15:20 LT (UTC+2), compared with $\mathrm{MS}^{2}$ spectra of authentic standards of vanillic acid $(\mathrm{m} / z$ 167), cis-pinonic acid $(m / z 183)$ and $c i s$-pinic acid $(m / z 185)$. The $\mathrm{MS}^{2}$ spectrum of $\operatorname{MBTCA}(m / z$ 203) is taken from an ambient filter sample measured with ESI-MS ${ }^{2}$ after chromatographic separation.

$\mathrm{PM}_{2.5}$ ambient aerosol. Diaterpenylic acid acetate has also been identified as an oxidation product of 1,8-cineol (Iinuma et al., 2009).

To conclude this section, it is worth mentioning that the structural identification becomes more complex with increasing molecular mass and therefore it cannot be concluded with certainty which exact compound contributes to which extent to the total signal at a specific $m / z$ ratio. However, having the possibility to perform in situ $\mathrm{MS}^{2}$ experiments of one selected $m / z$ ratio, which can comprise several different compounds, enables identification of the fragmentation markers, and helps to elucidate the chemical structure of unknown compounds.

\subsection{In situ $\mathrm{MS}^{2}$ measurements}

Figure 5 shows the major neutral losses from four different $\mathrm{m} / \mathrm{z}$ ratios measured in the gas and particle phase during the HUMPPA-COPEC 2010 campaign compared to the neutral losses of standard compounds of the same masses $(\mathrm{m} / z$ 167: vanillic acid; $m / z$ 183: pinonic acid; $m / z$ 185: pinic acid; and $m / z$ 203: MBTCA). The fragmentation was achieved by using the CID (collision-induced dissociation) mode, which briefly means that the target molecules of one $\mathrm{m} / \mathrm{z}$ ratio were isolated and subsequently fragmented by collisions with helium atoms inside the ion trap. The measurements were carried out on 22 July 2010, 13:20-15:20 LT (UTC+2) - air masses during this period came from the south-west. The 
experimental setup did not allow for measuring the fragmentation pattern of particle-phase compounds exclusively. $\mathrm{MS}^{2}$ fragments with a relative intensity less than $10 \%$ (of the base peak) are attributed to the "other" bin. Specific fragments which can be attributed to structural elements were included despite low intensities (e.g. $15 \mathrm{Da}$ loss due to a $\mathrm{CH}_{3}$ radical cleavage). In the Supplement all measured $\mathrm{MS}^{2}$ raw spectra are depicted.

The difference between online $\mathrm{MS}^{2}$ described here and offline $\mathrm{MS}^{2}$ spectra after chromatographic separation is that the online technique generates fragments of all isobaric compounds present, whereas the offline technique generates fragments which can unambiguously be assigned to one compound (assuming a complete chromatographic separation). Yasmeen et al. (2011) recently published an overview of $\mathrm{MS}^{n}$ spectra of several terpenoic acids using HPLC-(-)ESI$\mathrm{MS}^{n}$ measurements of filter extracts (selected isobaric compounds at $m / z 183, m / z 185, m / z 187$ and $m / z$ 203). These spectra allow for unambiguous differentiation between different biogenic organic acids. Typically, organic acids show the neutral loss of water $(18 \mathrm{Da})$ and $\mathrm{CO}_{2}(44 \mathrm{Da})$ - which can be observed during both online and offline $\mathrm{MS}^{2}$. However, other neutral losses which are more characteristic can help to confirm the identity of known compounds or support the structural elucidation of unknown compounds. In general, the $\mathrm{MS}^{2}$ field spectra show many more fragments than during online $\mathrm{MS}^{2}$ studies of terpene ozonolysis chamber experiments (Vogel et al., 2013) or after chromatographic separation (Yasmeen et al., 2011).

Among others, one organic acid which contributes to the signal at $m / z, 167$ is vanillic acid $\left(\mathrm{C}_{8} \mathrm{H}_{8} \mathrm{O}_{4}\right)$. Vanillic acid has been described, among many other methoxyphenols, as a biomass burning tracer (Simoneit et al., 1993), which can be directly emitted during burning processes or formed through heterogeneous reaction of coniferyl alcohol and ozone (Net et al., 2011). Justesen (2001) reported that the loss of $15 \mathrm{Da}$ during $\mathrm{MS}^{2}$ is a common neutral loss from methoxyphenolic structures and can be attributed to the cleavage of a $\mathrm{CH}_{3}$ radical from the methoxy group. The standard $\mathrm{MS}^{2}$ spectrum of vanillic acid shows a stronger loss of the $15 \mathrm{Da}$ fragment, suggesting that other organic acids than vanillic acid contribute to the signal measured on $m / z 167$.

Offline $\mathrm{MS}^{2}$ spectra of the compounds on $\mathrm{m} / \mathrm{z}$ 183, cispinonic acid and cis-caronic acid, show that the strongest neutral loss is $44 \mathrm{Da}$ and $72 \mathrm{Da}$, respectively (Yasmeen et al., 2011). Both neutral losses are observed in the online $\mathrm{MS}^{2}$ spectrum; especially the loss of $72 \mathrm{Da}$ contributes substantially, compared to the fragmentation pattern of other $\mathrm{m} / \mathrm{z}$ ratios. However, the $72 \mathrm{Da}$ fragment does not occur in the standard $\mathrm{MS}^{2}$ spectrum of cis-pinonic acid, supporting the fact that the $72 \mathrm{Da}$ fragment originates from cis-caronic acid. This indicates a high abundance of $c i s$-caronic acid in the ambient aerosol. Furthermore, Yasmeen et al. (2011) did show by $\mathrm{MS}^{3}$ analysis of the fragment ions $m / z 139$ and $m / z 111$ that the strongest ion formed from both acids was measured on $m / z$ 57. This signal appears in the online measurements already during $\mathrm{MS}^{2}$ (loss of $126 \mathrm{Da}$ ). This particular fragment was not measured at other $m / z$ ratios and therefore can be regarded as an unambiguous marker fragment for the identification of cis-pinonic and cis-caronic acid. The neutral loss of $28 \mathrm{Da}$ in the field experiment has not been described in the literature - possible fragments are $\mathrm{CO}$ or $\mathrm{C}_{2} \mathrm{H}_{4}$. The authentic standard cis-pinonic acid shows a small signal of the neutral loss of $15 \mathrm{Da}$; however, a reasonable fragmentation scheme explaining this fragment would be speculative.

The most pronounced neutral losses of $m / z 185$ are $18 \mathrm{Da}$ and $44 \mathrm{Da}$. Furthermore, the $\mathrm{MS}^{2}$ pattern shows a strong ion signal at $m / z 97$ (loss of $88 \mathrm{Da}$ ), which can be regarded as an evidence for a dicarboxylic acid (cleavage of $2 \mathrm{CO}_{2}$ ). This seems reasonable since cis-pinic acid, cis-caric acid and limonic acid are dicarboxylic acids. Surprisingly, only limonic acid shows the signal $\mathrm{m} / z 97$ in offline $\mathrm{MS}^{2}$ (Yasmeen et al., 2011). As can be seen in Fig. 5, the neutral losses of cis-pinic acid are mainly water and $\mathrm{CO}_{2}$. However, another unique fragment in the ambient $\mathrm{MS}^{2}$ appears on $\mathrm{m} / z 115$ (neutral loss of $70 \mathrm{Da}$ ) - it can be observed online and offline. Yasmeen et al. (2011) suggested a McLafferty type rearrangement of ketolimononic acid resulting in the ion at $m / z$ 115. This indicates that limonic acid and ketolimononic acid are significantly abundant in the ambient aerosol at Hyytiälä. The loss of a neutral $28 \mathrm{Da}$ fragment from the molecular ion $\mathrm{m} / z 185$ might be attributed to $\mathrm{CO}$, and therefore a possible indication for semialdehydes, e.g. 4-hydroxypinalic-3-acid (Jaoui and Kamens, 2003) or the $\Delta^{3}$-carene derivative $\mathrm{OH}$ 3 -caralic acid (Ma et al., 2009). Unfortunately, these compounds are not available commercially. One possible fragmentation mechanism of $\mathrm{OH}-3$-caralic acid is proposed in Fig. 6, giving an explanation for the neutral loss of $28 \mathrm{Da}$. All of the proposed fragments in Fig. 6 can be found in the online $\mathrm{MS}^{2}$ spectrum of $m / z 185$, some of them only at low intensities (see Supplement for the MS ${ }^{2}$ spectrum of $m / z$ 185). If the semialdehydes partition to a high degree to the gas phase or if oxidation during filter sampling occurs, it can be explained why the neutral loss of $28 \mathrm{Da}$ has up to now not been observed in $\mathrm{MS}^{2}$ studies of ambient filter measurements.

The $\mathrm{MS}^{2}$ fragmentation pattern of $\mathrm{m} / z 203$ shows the strongest loss of water compared to the pattern of the other $m / z$ ratios. Due to the lack of a MBTCA standard, the shown reference $\mathrm{MS}^{2}$ spectrum refers to the measurement of an ambient filter after chromatographic separation. However, the spectra shown are consistent with the observations made by Yasmeen et al. (2011), where two different MW 204 compounds in ambient nighttime aerosol show the ion $\mathrm{m} / \mathrm{z} 185$ during $\mathrm{MS}^{2}$. Offline $\mathrm{MS}^{3}$ from MBTCA shows a weak signal on $m / z 115$ which corresponds to the loss of two carboxylic acid groups, which was also observed during the ambient online $\mathrm{MS}^{2}$ measurement of $\mathrm{m} / z 203$ (neutral loss of $88 \mathrm{Da}$ ). The loss of $28 \mathrm{Da}$ indicates that further unidentified organic acids might contribute to the signal on $m / z 203$. 


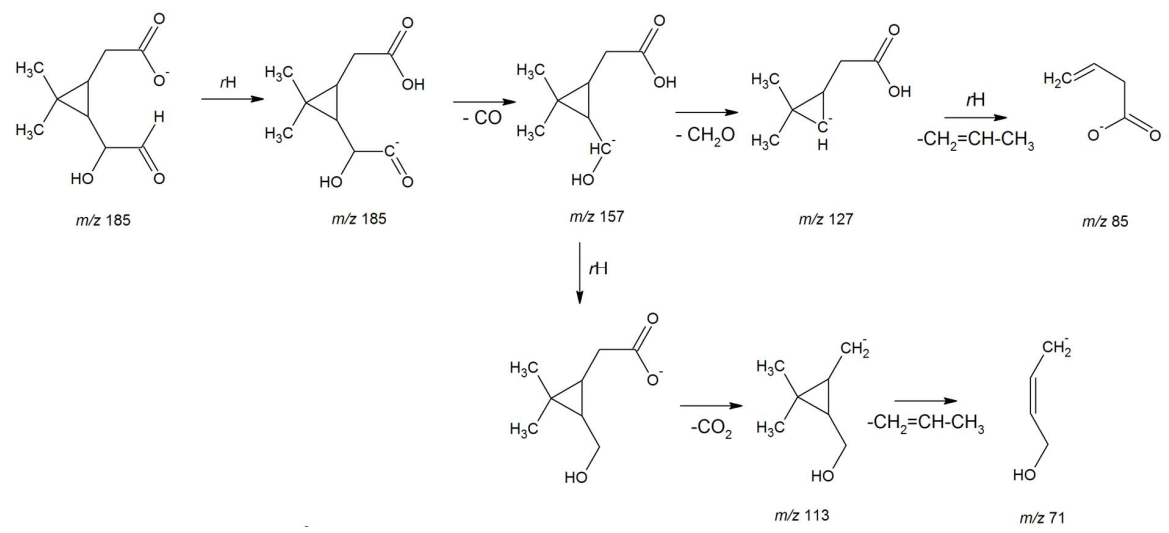

Fig. 6. Proposed $\mathrm{MS}^{2}$ fragmentation mechanism of $\mathrm{OH}-3$-caralic acid.

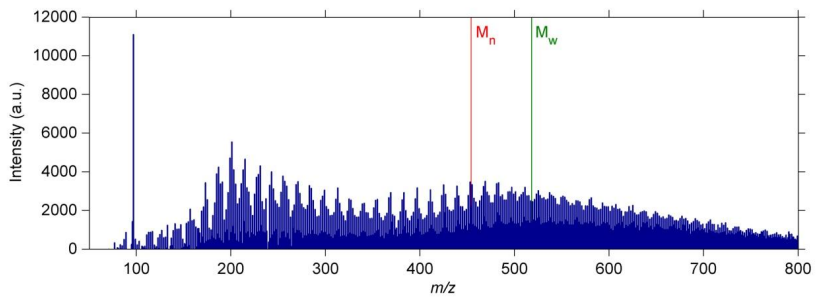

Fig. 7. Average spectrum of compounds measured in the negative APCI mode on 29 July 2010, 13:00-14:30 LT (UTC+2), during a period influenced by the severe biomass burning in central Russia. $M_{n}$ is the number average molecular weight and $M_{\mathrm{W}}$ the weight average molecular weight.

\subsection{Average OA molecular weight}

Since a soft ionization process is used, which in general generates molecular ions, it is obvious to use this information to determine the average molecular weight of the organic fraction $\overline{\mathrm{MW}}_{\mathrm{om}}$ in the particle phase. The average molecular weight is of particular importance for the calculation of gasto-particle partitioning coefficients, as was recently stressed by Pankow (2011).

The average molecular weight in the particulate phase can be described by the number average molecular weight $\overline{\mathrm{MW}}_{n}$ (Eq. 1), or the weight average molecular weight $\overline{\mathrm{MW}}_{\mathrm{w}}$ (Eq. 2), where $N_{i}$ is the number of molecules $i$ (represented by the $m / z$ intensity) and $M_{i}$ is the molecular mass of $i$ (Kalberer et al., 2006).

$\overline{\mathrm{MW}}_{n}=\frac{\sum N_{i} M_{i}}{\sum N_{i}}$

$\overline{\mathrm{MW}}_{\mathrm{w}}=\frac{\sum N_{i} M_{i}^{2}}{\sum N_{i} M_{i}}$

Figure 7 shows a negative ion mode spectrum of the particle-phase signal (90 min average) during 29 July 2010,
13:00-14:30 LT $(\mathrm{UTC}+2)$. In this particular spectrum the calculation of $\overline{\mathrm{MW}}_{n}$ and $\overline{\mathrm{MW}}_{\mathrm{w}}$ results in $454 \mathrm{~g} \mathrm{~mol}^{-1}$ and $518 \mathrm{~g} \mathrm{~mol}^{-1}$, respectively. It should be stressed that the figure is not representative for the campaign average, but it indicates that OA components can exceed $500 \mathrm{Da}$ significantly in transported plumes from biomass burning events.

Using Eq. (1) to calculate $\overline{\mathrm{MW}}_{\mathrm{om}}$ of each scan and averaging the values over the duration of the campaign results in $\overline{\mathrm{MW}}_{\mathrm{om}} \approx 300 \mathrm{~g} \mathrm{~mol}^{-1}$, which is on the upper end of the range described by Kiss et al. (2003). For simplicity, in the calculation of the campaign average $\overline{\mathrm{MW}}_{\text {om }}$, the ideal case that all ions are singly charged, do not fragment and have similar ionization efficiencies was assumed. Furthermore, the calculation includes the assumption that the molar mass distribution of the ions, which are formed in the negative mode, is equal to the molar mass distribution of all compounds in the particle phase. The determination of $\overline{\mathrm{MW}}_{\mathrm{om}}$ using mass spectrometry can be seriously biased as is extensively discussed in the Supplement. Nevertheless, Kiss et al. (2003) demonstrated by using two different techniques for the determination of $\overline{\mathrm{MW}}_{\mathrm{om}}$, namely electrospray ionization mass spectrometry and vapour pressure osmometry, that both techniques agree quite well with a slight shift towards lower values obtained with the MS method.

In previous field work by Williams et al. (2010) a $\overline{\mathrm{MW}}_{\mathrm{om}}$ of $220 \mathrm{~g} \mathrm{~mol}^{-1}$ was observed by using TAG (thermal desorption aerosol gas chromatograph). Kalberer et al. (2006) observed $\overline{\mathrm{MW}}_{\text {om }}$ values between 300 and $400 \mathrm{~g} \mathrm{~mol}^{-1}$ in a smog chamber experiment with isoprene and $\alpha$-pinene by the use of MALDI-MS (matrix-assisted laser desorption/ionization MS). This shows that $\overline{\mathrm{MW}}_{\text {om }}$ is on average variable in the range between 200 and $400 \mathrm{~g} \mathrm{~mol}^{-1}$. Under exceptional circumstances (e.g. aged biomass burning aerosol) the average molecular weight can exceed this range. 


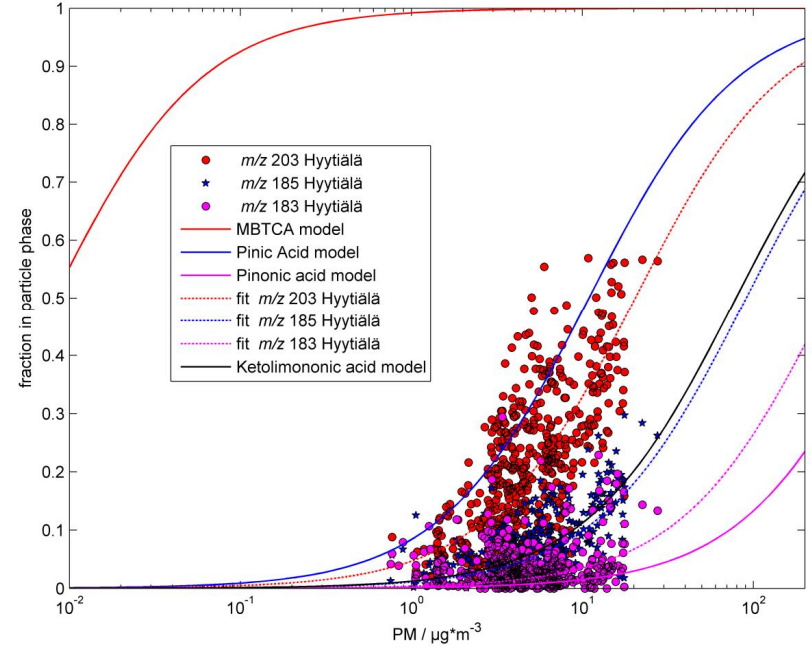

Fig. 8. Modelled (solid lines) gas-to-particle partitioning of three distinct organic acids versus the measured (dashed lines) gas-toparticle partitioning of the respective $\mathrm{m} / \mathrm{z}$ ratios. The model assumes instantaneous partitioning (liquid particle phase). The measured data points are averaged on an hourly basis. For clarity, separated $m / z$ data points are shown Fig. S3.

\subsection{Gas-to-particle partitioning of organic acids}

The modelled gas-to-particle partitioning of three distinct biogenic organic acids, which are substantially different in their volatility, is represented by the solid lines in Fig. 8. The organic acids in question are cis-pinonic acid, cis-pinic acid and MBTCA, which are first- and second-generation oxidation products from specific monoterpenes. Equation (3), based on the partitioning model of Liang and Pankow (1996), was used to calculate the fraction in particle phase $f_{\mathrm{p}, i}$ of the compound $i$ as a function of the mass concentration of absorptive particulate matter PM $\left(\mu \mathrm{g} \mathrm{m}^{-3}\right)$ and the partitioning coefficient $K_{\mathrm{p}, i}\left(\mathrm{~m}^{3} \mu \mathrm{g}^{-1}\right)$ of the compound $i$. To determine $f_{\mathrm{p}, i}$ from the measurements, the signal of species $i$ in the particle phase $F_{i}$ was divided by the sum of the gas-phase signal $A_{i}$ and the particle-phase signal $F_{i}$ :

$f_{\mathrm{p}, i}=\frac{K_{\mathrm{p}, i} \mathrm{PM}}{1+K_{\mathrm{p}, i} \mathrm{PM}}=\frac{F_{i}}{F_{i}+A_{i}}$.

The equilibrium partitioning coefficient $K_{\mathrm{p}, i}\left(\mathrm{~m}^{3} \mu \mathrm{g}^{-1}\right)$ (Eq. 4; Pankow, 1994) depends on the fraction of PM that is organic matter $f_{\mathrm{om}}$, on the temperature $T(\mathrm{~K})$, on the average molecular weight of the particulate organic matter $\overline{\mathrm{MW}}_{\text {om }}(\mathrm{g}$ mol $^{-1}$ ), on the activity coefficient $\gamma_{i}$ (which describes the non-ideal particle-molecule interactions) and on the pure liquid vapour pressure $p_{\mathrm{L}, i}^{\mathrm{o}}$ (Torr) of the respective compound $i$. $R$ is the gas constant, 760 a pressure conversion factor and $10^{6}$ a mass conversion factor:

$K_{\mathrm{p}, i}=\frac{f_{\mathrm{om}} 760 R T}{\overline{\mathrm{MW}}_{\mathrm{om}} \gamma_{i} p_{\mathrm{L}, i}^{\mathrm{o}} 10^{6}}$
To model the gas-to-particle partitioning of the compounds $c i s$-pinonic acid, cis-pinic acid and MBTCA, the par-

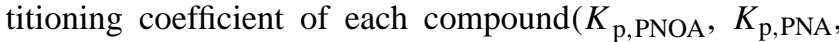
$\left.K_{\mathrm{p}, \mathrm{MBTCA}}\right)$ was calculated using Eq. (4) with the following parameters: the campaign average value $f_{\text {om }}=0.64$, $T=294 \mathrm{~K}, \overline{\mathrm{MW}}_{\mathrm{om}}=300 \mathrm{~g} \mathrm{~mol}^{-1}, \gamma_{i}=1$, and the predicted vapour pressure at $294 \mathrm{~K}$ (see Table 2) using the SIMPOL.1 group contribution method (Pankow and Asher, 2008). The organic matter factor $f_{\text {om }}$ was determined by dividing the campaign average of OA (AMS data) by the total aerosol mass including black carbon (AMS and Aethalometer). The resulting $K_{\mathrm{p}, i}$ for the three acids are shown in Table 2 and represented by the solid lines in Fig. 8. The $C_{i}^{*}$ value $\left(\mu \mathrm{g} \mathrm{m}^{-3}\right)$ in Table 2 is the saturation concentration, which is basically the inverse of the partitioning coefficient $K_{\mathrm{p}, i}$, both describing the volatility of the compound $i$ in a mixture (Donahue et al., 2006).

The online partitioning measurements of the related $\mathrm{m} / \mathrm{z}$ ratios of the three acids are represented by one-hour average points during the time when APCI-IT-MS and AMS were running simultaneously. The corresponding PM values are averaged in the same time intervals from AMS and Aethalometer data. All values below $0.7 \mu \mathrm{g} \mathrm{m}^{-3}$ were taken out due to uncertainty in the measurements. The resulting data points of each $m / z$ ratio are fitted using Eq. (3). The resulting $K_{\mathrm{p}, i}$ values are stated in Table 2 and the fit of the measured data is represented by the dotted lines in Fig. 8.

By comparing the model predictions with the measured $\mathrm{m} / z$ partitioning values, it can be seen that model and observation do show the same trend in volatility from the highestvolatility cis-pinonic acid to the lowest-volatility MBTCA. However, the huge offset between the partitioning model and the measurements (especially for $m / z$ 203) does not necessarily mean that either the model or the measurement is wrong, because isobaric interference of more volatile compounds on the same $m / z$ ratio can shift the measured partitioning significantly. For example, as has been shown in Sect. 3.3, the signal at $m / z 185$ does not only emerge from one acid. Predicting the vapour pressure for the $m / z 185 \mathrm{ke}$ tolimononic acid at $T=294 \mathrm{~K}$ results in $p_{\mathrm{L}, \mathrm{KETOLMNOA}}^{\mathrm{o}}=$ $3.1 \times 10^{-6}$ Torr, suggesting that ketolimononic acid is almost one order of magnitude more volatile than $c i s$-pinic acid. The predicted partitioning of ketolimononic acid fits well to the observations at $m / z 185$, as is shown by the black solid line in Fig. 8. Thus, isobaric interferences of organic species having different vapour pressures might be one explanation for the observed differences between model and measurements.

The model calculation assumes that the particles are in a liquid state, that all of the particulate matter is involved in the partitioning and that equilibrium is reached very fast (instantaneous equilibrium). However, recent studies indicate that ambient particles can occur in a glassy or semisolid state, which implies much slower diffusion exchange between the surface and the inner core of a particle (Virtanen 
Table 2. Modelled and measured partitioning coefficients of three distinct organic acids.

\begin{tabular}{llll}
\hline & Cis-Pinonic acid & Cis-Pinic Acid & MBTCA \\
\hline$p_{\mathrm{L}, i}^{\mathrm{o}}(\mathrm{Torr})^{\mathrm{a}}$ & $2.55 \times 10^{-5}$ & $4.28 \times 10^{-7}$ & $3.16 \times 10^{-10}$ \\
$K_{\mathrm{p}, i}\left(\mathrm{~m}^{3} \mu \mathrm{g}^{-1}\right)^{\mathrm{b}}$ & $1.5 \times 10^{-3}$ & $9.1 \times 10^{-2}$ & 124 \\
$C^{*}\left(\mu \mathrm{g} \mathrm{m}^{-3}\right)^{\mathrm{b}}$ & 667 & 11 & $8.1 \times 10^{-3}$ \\
& $\boldsymbol{m} / \boldsymbol{z} \mathbf{1 8 3}$ Hyytiälä & $\boldsymbol{m} / \boldsymbol{z} \mathbf{1 8 5}$ Hyytiälä & $\boldsymbol{m} / \boldsymbol{z} \mathbf{2 0 3}$ Hyytiälä \\
\hline$K_{\mathrm{p}, i}\left(\mathrm{~m}^{3} \mu \mathrm{g}^{-1}\right)^{\mathrm{c}}$ & $3.6 \times 10^{-3}$ & $1.1 \times 10^{-2}$ & $4.9 \times 10^{-2}$ \\
$C^{*}\left(\mu \mathrm{g} \mathrm{m}^{-3}\right)^{\mathrm{c}}$ & 278 & 91 & 20 \\
\hline
\end{tabular}

a Predicted by the SIMPOL.1 model at $294 \mathrm{~K}$ (Pankow and Asher, 2008).

$\mathrm{b}$ Based on campaign average values of $f_{\mathrm{om}}=0.64$ and $\overline{\mathrm{MW}}_{\mathrm{om}}=300 \mathrm{~g} \mathrm{~mol}^{-1}, T=294 \mathrm{~K}$ and $\gamma_{i}=1$.

${ }^{\mathrm{c}}$ Campaign average fit using Eq. (3).

et al., 2010; Shiraiwa et al., 2011). Therefore, the equilibration timescale of the partitioning of organic compounds between gas and particle phase has to be taken into account, since the assumption of instantaneous equilibration can lead to discrepancies in the mass distribution between gas and particle phase. Recently, Shiraiwa and Seinfeld (2012) demonstrated that the gas-to-particle partitioning of semi- and lowvolatile compounds is far from equilibrium if the particle phase is in a semi-solid state. As a consequence, the instantaneous partitioning model underestimates the concentration of low-volatile compounds in the gas phase by several orders of magnitude. In fact, our findings of unexpectedly high gas-phase concentrations can also be interpreted as experimental evidence that the aerosol during HUMPPA-COPEC was highly viscous and the partitioning not nearly in equilibrium. We are aware of the fact that the application of a water-based concentrator changes the gas-to-particle partitioning; however, the gas-phase concentration was calculated as a lower limit estimate (see Supplement) and thus the partitioning might be shifted even more towards the gas phase.

The observed scattering of the compounds around the fitted function in Fig. 8 can be explained by a varying $f_{\text {om }}$ value. To illustrate the influence of $f_{\text {om }}$ on the partitioning, Fig. 9 shows the signals of $m / z 203$ (30 min average) including the respective colour-coded $f_{\text {om }}$ value which was measured by AMS (and Aethalometer for BC) simultaneously. Using Eq. (4) with $f_{\text {om }}=0.3$ to 1.0 based on the basis of the fit of all measured data points with $p_{\mathrm{L}, m / z 203}^{\mathrm{o}}=8.2 \times 10^{-7}$ and $f_{\mathrm{om}}=0.64$ (campaign average) shows that the broad distribution of the partitioning of one $m / z$ ratio substantially depends on the $f_{\text {om }}$ value, as is predicted by the model. The remaining bias between model and observation can most probably be explained by non-unity $\gamma_{i}$ values. If the activity coefficients is larger than 1 , the particle phase is forced to separate, due to e.g. non-solubility between polar and non-polar molecules. In turn, an activity coefficient $<1$ tends to stabilize the particle phase due to intermolecular binding forces. As can be seen in Fig. 9, both phenomena can be observed. To explain the offset above $f_{\mathrm{om}}=1$, it is assumed that the organic molecules are highly oxidized, so that they can build

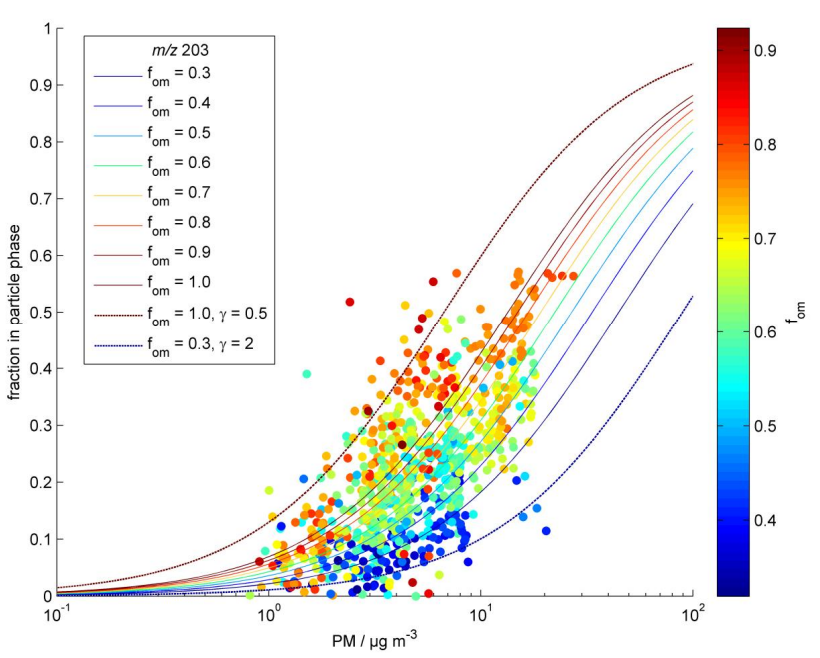

Fig. 9. Measured gas-to-particle partitioning of $m / z 203$ with colour-coded organic matter fraction. All modelled functions are based on the average fit of all data points with the average campaign of $f_{\text {om }}=0.64$ and $\gamma=1$. The measured data points are averaged on a basis of $30 \mathrm{~min}$.

up strong intermolecular binding forces (hydrogen bonding). Thus, the activity coefficient becomes $<1$ and the fraction in the particle phase increases. This is illustrated by the dashed red line, which is based on $f_{\mathrm{om}}=1$ and $\gamma_{i}=0.5$. The other case is that the activity coefficient $>1$ describes destabilizing forces such as "salting out" effects, which results in a higher fraction in the gas phase. The dashed blue line $\left(f_{\mathrm{om}}=0.3\right.$ and $\gamma_{i}=2$ ) shows this tendency pushing semi-volatile compounds into the gas phase.

\section{Conclusions}

The organic aerosol composition during the HUMPPACOPEC 2010 boreal forest field study was presented with special attention towards the organic acid fraction. Good agreement between online APCI-IT-MS and AMS and offline FTIR measurements was achieved. AMS-PMF analysis 
indicated that the aerosol was highly oxidized, especially during the arrival of an aged biomass burning plume from the Russian wildfires. During this biomass burning plume, the soft ionization APCI-IT-MS measured high MW organic acid compounds up to $800 \mathrm{Da}$ in the particle phase.

Comparison between laboratory experiments and ambient measurements showed that the chamber-generated $\alpha$-pinene and $\Delta^{3}$-carene SOA is in terms of the mass spectral pattern more similar to the ambient gas phase than to the ambient particle phase, most probably due to aging processes of the particle phase in ambient air. Concerning the online identification of single organic acid species, it has been shown that a first step to overcome the problem of isobaric interference is utilizing the $\mathrm{MS}^{2}$ technique, which can generate distinctive structural fragments. Unattributed $\mathrm{MS}^{2}$ fragments indicate the existence of unidentified compounds in the ambient gas and particle phase at Hyytiälä. Applying this technique in future field studies for measuring $\mathrm{MS}^{n}$ of either gas or particle phase solely can resolve how far isobaric compounds partition to a different extent between gas and particle phase due to different functionality/volatility. Further improvement of this technique can open up the possibility of unambiguous online identification and quantification of isobaric species in ambient organic aerosol.

It has been shown that the utilization of complementary online mass spectrometric techniques, such as the combination of APCI-IT-MS and AMS, enables the determination of the gas-to-particle partitioning of specific $m / z$ ratios at a high temporal resolution. It has been considered that, despite the abundance of unidentified compounds, the phase state (and thus the equilibration timescale) of aerosol particles might account for the high observed gas-phase concentrations of low-volatility organic compounds. Therefore, in future campaigns it might be essential to measure the phase state of particles in order to study its effect on the partitioning of lowvolatility organic compounds.

\section{Supplementary material related to this article is available online at http://www.atmos-chem-phys.net/13/ 10933/2013/acp-13-10933-2013-supplement.pdf.}

Acknowledgements. ALV and TH gratefully acknowledge the Max Planck Institute for Chemistry in Mainz and the Max Planck Graduate Center for financial support and the possibility to participate in the HUMPPA-COPEC 2010 field campaign. Furthermore they acknowledge the support by the SMEAR II team during the campaign, Caroline Oehm and Ottmar Moehler of the Karlsruhe Institute of Technology for the loan of the PCVI and Horst Fischer and Rainer Königstedt for the distribution of the CO data. ALC gratefully acknowledges support by the Department of Energy Office of Science Graduate Fellowship Program (DOE SCGF).

The entire HUMPPA-COPEC team is grateful for the support of the Hyytiälä site engineers and staff. Support of the European Com- munity - Research Infrastructure Action under the FP6 "Structuring the European Research Area" programme, EUSAAR contract no. RII3-CT-2006-026140, is gratefully acknowledged.

The campaign measurements and analyses were supported by the ERC Grant ATMNUCLE (project no. 227463), Academy of Finland Centre of Excellence programme (project no. 1118615), the European Integrated project on Aerosol Cloud Climate and Air Quality Interactions EUCAARI (project no. 036833-2), the EUSAAR TNA (project No. 400586), and the IMECC TA (project no. 4006261).

The authors gratefully acknowledge the NOAA Air Resources Laboratory (ARL) for the provision of the HYSPLIT transport and dispersion model and READY website (http://ready.arl.noaa.gov) used in this publication.

Edited by: D. Heard

\section{References}

Alfarra, M. R., Hamilton, J. F., Wyche, K. P., Good, N., Ward, M. W., Carr, T., Barley, M. H., Monks, P. S., Jenkin, M. E., Lewis, A. C., and McFiggans, G. B.: The effect of photochemical ageing and initial precursor concentration on the composition and hygroscopic properties of $\beta$-caryophyllene secondary organic aerosol, Atmos. Chem. Phys., 12, 6417-6436, doi:10.5194/acp12-6417-2012, 2012.

Allan J., Jimenez J., Williams P., Alfarra M., Bower K., Jayne J., Coe H., and Worsnop D. R.: Quantitative sampling using an Aerodyne aerosol mass spectrometer: 1 . Techniques of data interpretation and error analysis, J. Geophys. Res.-Atmos., 108, 4090, doi:10.1029/2002JD002358, 2003.

Allan J., Delia A., Coe H., Bower K., Alfarra M.R., Jimenez J., Middlebrook A., Drewnick F., Onasch T., Canagaratna M., Jayne J., and Worsnop D. R.: A generalised method for the extraction of chemically resolved mass spectra from Aerodyne aerosol mass spectrometer data, J. Aerosol Sci., 35, 909-922, 2004.

Andreae, M. O. and Merlet, P.: Emission of trace gases and aerosols from biomass burning, Global Biochem. Cy., 15, 955966, doi:10.1029/2000GB001382, 2001.

Aufmhoff, H., Hanke, M., Uecker, J., Schlager, H., and Arnold, F.: An ion trap CIMS instrument for combined measurements of atmospheric $\mathrm{OH}$ and $\mathrm{H} 2 \mathrm{SO} 4$ : First test measurements above and inside the planetary boundary layer, Int. J. Mass Spectrom., 308, 26-34, doi:10.1016/j.ijms.2011.07.016, 2011.

Bartmess, J. E.: Gas-Phase Equilibrium Affinity Scales and Chemical Ionization Mass-Spectrometry, Mass Spectrom. Rev., 8, 297 343, doi:10.1002/mas.1280080502, 1989.

Bonan, G. B.: Forests and climate change: Forcings, feedbacks, and the climate benefits of forests, Science, 320, 1444-1449, doi:10.1126/science.1155121, 2008.

Caldwell, G., Renneboog, R., and Kebarle, P.: Gas phase acidities of aliphatic carboxylic acids, based on measurements of proton transfer equilibria, Canadian Journal of Chemistry-Revue Canadienne De Chimie, 67, 611-618, doi:10.1139/v89-092, 1989.

Canagaratna, M. R., Jayne, J. T., Jimenez, J. L., Allan, J. D., Alfarra, M. R., Zhang, Q., Onasch, T. B., Drewnick, F., Coe, H., Middlebrook, A., Delia, A., Williams, L. R., Trimborn, A. M., Northway, M. J., DeCarlo, P. F., Kolb, C. E., Davidovits, P., and Worsnop, D. R.: Chemical and microphysical characterization of ambient aerosols with the aerodyne aerosol mass spectrome- 
ter, Mass Spectrom. Rev., 26, 185-222, doi:10.1002/mas.20115, 2007.

Claeys, M., Iinuma, Y., Szmigielski, R., Surratt, J. D., Blockhuys, F., van Alsenoy, C., Boege, O., Sierau, B., Gomez-Gonzalez, Y., Vermeylen, R., van der Veken, P., Shahgholi, M., Chan, A. W. H., Herrmann, H., Seinfeld, J. H., and Maenhaut, W.: Terpenylic Acid and Related Compounds from the Oxidation of alpha-Pinene: Implications for New Particle Formation and Growth above Forests, Environ. Sci. Technol., 43, 6976-6982, doi:10.1021/es9007596, 2009.

Corrigan, A. L., Russell, L. M., Takahama, S., Äijälä, M., Ehn, M., Junninen, H., Rinne, J., Petäjä, T., Kulmala, M., Vogel, A. L., Hoffmann, T., Ebben, C. J., Geiger, F. M., Chhabra, P., Seinfeld, J. H., Worsnop, D. R., Song, W., Auld, J., and Williams, J.: Biogenic and biomass burning organic aerosol in a boreal forest at Hyytiälá, Finland, during HUMPPA-COPEC 2010, Atmos. Chem. Phys. Discuss., 13, 16151-16210, doi:10.5194/acpd-1316151-2013, 2013.

Dal Maso, M., Sogacheva, L., Aalto, P. P., Riipinen, I., Komppula, M., Tunved, P., Korhonen, L., Suur-Uski, V., Hirsikko, A., Kurten, T., Kerminen, V. M., Lihavainen, H., Viisanen, Y., Hansson, H.-C., and Kulmala, M.: Aerosol size distribution measurements at four Nordic field stations: identification, analysis and trajectory analysis of new particle formation bursts, Tellus B-, 59, 350-361, doi:10.1111/j.1600-0889.2007.00267.x, 2007.

Docherty, K. S., Stone, E. A., Ulbrich, I. M., DeCarlo, P. F., Snyder, D. C., Schauer, J. J., Peltier, R. E., Weber, R. J., Murphy, S. M., Seinfeld, J. H., Grover, B. D., Eatough, D. J., and Jimenez, J. L.: Apportionment of Primary and Secondary Organic Aerosols in Southern California during the 2005 Study of Organic Aerosols in Riverside (SOAR-1), Environ. Sci. Technol., 42, 7655-7662, doi:10.1021/es8008166, 2008.

Donahue, N. M., Robinson, A. L., Stanier, C. O., and Pandis, S. N.: Coupled partitioning, dilution, and chemical aging of semivolatile organics, Environ. Sci. Technol., 40, 2635-2643, doi:10.1021/es052297c, 2006.

Donahue, N. M., Epstein, S. A., Pandis, S. N., and Robinson, A. L.: A two-dimensional volatility basis set: 1. organic-aerosol mixing thermodynamics, Atmos. Chem. Phys., 11, 3303-3318, doi:10.5194/acp-11-3303-2011, 2011.

Donahue, N. M., Kroll, J. H., Pandis, S. N., and Robinson, A. L.: A two-dimensional volatility basis set - Part 2: Diagnostics of organic-aerosol evolution, Atmos. Chem. Phys., 12, 615-634, doi:10.5194/acp-12-615-2012, 2012a.

Donahue, N. M., Henry, K. M., Mentel, T. F., Kiendler-Scharr, A., Spindler, C., Bohn, B., Brauers, T., Dorn, H. P., Fuchs, H., Tillmann, R., Wahner, A., Saathoff, H., Naumann, K.-H., Moehler, O., Leisner, T., Mueller, L., Reinnig, M.-C., Hoffmann, T., Salo, K., Hallquist, M., Frosch, M., Bilde, M., Tritscher, T., Barmet, P., Praplan, A. P., DeCarlo, P. F., Dommen, J., Prevot, A. S. H., and Baltensperger, U.: Aging of biogenic secondary organic aerosol via gas-phase $\mathrm{OH}$ radical reactions, P. Natl. Acad. Sci. USA, 109, 13503-13508, doi:10.1073/pnas.1115186109, 2012b.

Draxler, R. R. and Rolph G. D.: HYSPLIT (HYbrid Single-Particle Lagrangian Integrated Trajectory) Model access via NOAA ARL READY Website: http://ready.arl.noaa.gov/HYSPLIT.php, NOAA Air Resources Laboratory, Silver Spring, MD, 2013.

Drewnick, F., Hings, S. S., DeCarlo, P., Jayne, J. T., Gonin, M., Fuhrer, K., Weimer, S., Jimenez, J. L., Demerjian, K. L., Bor- rmann, S., and Worsnop, D. R.: A new time-of-flight aerosol mass spectrometer (TOF-AMS) - Instrument description and first field deployment, Aerosol Sci. Technol., 39, 637-658, doi:10.1080/02786820500182040, 2005.

Geller, M. D., Biswas, S., Fine, P. A., and Sioutas, C.: A new compact aerosol concentrator for use in conjunction with low flow-rate continuous aerosol instrumentation, J. Aerosol Sci., 36, 1006-1022, doi:10.1016/j.jaerosci.2004.11.015, 2005.

Glasius, M., Duane, M., and Larsen, B. R.: Determination of polar terpene oxidation products in aerosols by liquid chromatography-ion trap mass spectrometry, J. Chromatography A, 833, 121-135, doi:10.1016/s0021-9673(98)01042-5, 1999.

Glasius, M., Lahaniati, M., Calogirou, A., Di Bella, D., Jensen, N. R., Hjorth, J., Kotzias, D., and Larsen, B. R.: Carboxylic acids in secondary aerosols from oxidation of cyclic monoterpenes by ozone, Environ. Sci. Technol., 34, 1001-1010, doi:10.1021/es990445r, 2000.

Goldstein, A. H. and Galbally, I. E.: Known and unexplored organic constituents in the earth's atmosphere, Environ. Sci. Technol., 41, 1514-1521, doi:10.1021/es072476p, 2007.

Gómez-González, Y., Wang, W., Vermeylen, R., Chi, X., Neirynck, J., Janssens, I. A., Maenhaut, W., and Claeys, M.: Chemical characterisation of atmospheric aerosols during a 2007 summer field campaign at Brasschaat, Belgium: sources and source processes of biogenic secondary organic aerosol, Atmos. Chem. Phys., 12, 125-138, doi:10.5194/acp-12-125-2012, 2012.

Hall, W. A., Pennington, M. R., and Johnston, M. V.: Molecular Transformations Accompanying the Aging of Laboratory Secondary Organic Aerosol, Environ. Sci. Technol., 47, 2230-2237, doi:10.1021/es303891q, 2013.

Hallquist, M., Wenger, J. C., Baltensperger, U., Rudich, Y., Simpson, D., Claeys, M., Dommen, J., Donahue, N. M., George, C., Goldstein, A. H., Hamilton, J. F., Herrmann, H., Hoffmann, T., Iinuma, Y., Jang, M., Jenkin, M. E., Jimenez, J. L., Kiendler-Scharr, A., Maenhaut, W., McFiggans, G., Mentel, Th. F., Monod, A., Prévôt, A. S. H., Seinfeld, J. H., Surratt, J. D., Szmigielski, R., and Wildt, J.: The formation, properties and impact of secondary organic aerosol: current and emerging issues, Atmos. Chem. Phys., 9, 5155-5236, doi:10.5194/acp-9-51552009, 2009.

Hari, P. and Kulmala, M.: Station for measuring ecosystematmosphere relations (SMEAR II), Boreal Environ. Res., 10, 315-322, 2005.

Hoffmann, T., Bandur, R., Marggraf, U., and Linscheid, M.: Molecular composition of organic aerosols formed in the alpha-pinene/O-3 reaction: Implications for new particle formation processes, J. Geophys. Res.-Atmos., 103, 25569-25578, doi:10.1029/98jd01816, 1998.

Hoffmann, T., Bandur, R., Hoffmann, S., and Warscheid, B.: Online characterization of gaseous and particulate organic analytes using atmospheric pressure chemical ionization mass spectrometry, Spectrochim. Acta, Part B, 57, 1635-1647, doi:10.1016/S05848547(02)00111-8, 2002.

Inuma, Y., Boege, O., Keywood, M., Gnauk, T., and Herrmann, H.: Diaterebic Acid Acetate and Diaterpenylic Acid Acetate: Atmospheric Tracers for Secondary Organic Aerosol Formation from 1,8-Cineole Oxidation, Environ. Sci. Technol., 43, 280 285, doi:10.1021/es802141v, 2009. 
Jaoui, M. and Kamens, R. M.: Gaseous and particulate oxidation products analysis of a mixture of alpha-pinene plus betapinene/O-3/air in the absence of light and alpha-pinene plus betapinene/NOx/air in the presence of natural sunlight, J. Atmos. Chem., 44, 259-297, doi:10.1023/a:1022977427523, 2003.

Jaoui, M., Corse, E., Kleindienst, T. E., Offenberg, J. H., Lewandowski, M., and Edney, E. O.: Analysis of secondary organic aerosol compounds from the photooxidation of d-limonene in the presence of NOX and their detection in ambient PM2.5, Environ. Sci. Technol., 40, 3819-3828, doi:10.1021/es052566z, 2006.

Jayne, J. T., Leard, D. C., Zhang, X. F., Davidovits, P., Smith, K. A., Kolb, C. E., and Worsnop, D. R.: Development of an aerosol mass spectrometer for size and composition analysis of submicron particles, Aerosol Sci. Technol., 33, 49-70, doi:10.1080/027868200410840, 2000.

Jimenez, J. L., Jayne, J. T., Shi, Q., Kolb, C. E., Worsnop, D. R., Yourshaw, I., Seinfeld, J. H., Flagan, R. C., Zhang, X. F., Smith, K. A., Morris, J. W., and Davidovits, P.: Ambient aerosol sampling using the Aerodyne Aerosol Mass Spectrometer, J. Geophys. Res.-Atmos., 108, 8425, doi:10.1029/2001jd001213, 2003.

Jimenez, J. L., Canagaratna, M. R., Donahue, N. M., Prevot, A. S. H., Zhang, Q., Kroll, J. H., DeCarlo, P. F., Allan, J. D., Coe, H., Ng, N. L., Aiken, A. C., Docherty, K. S., Ulbrich, I. M., Grieshop, A. P., Robinson, A. L., Duplissy, J., Smith, J. D., Wilson, K. R., Lanz, V. A., Hueglin, C., Sun, Y. L., Tian, J., Laaksonen, A., Raatikainen, T., Rautiainen, J., Vaattovaara, P., Ehn, M., Kulmala, M., Tomlinson, J. M., Collins, D. R., Cubison, M. J., Dunlea, E. J., Huffman, J. A., Onasch, T. B., Alfarra, M. R., Williams, P. I., Bower, K., Kondo, Y., Schneider, J., Drewnick, F., Borrmann, S., Weimer, S., Demerjian, K., Salcedo, D., Cottrell, L., Griffin, R., Takami, A., Miyoshi, T., Hatakeyama, S., Shimono, A., Sun, J. Y., Zhang, Y. M., Dzepina, K., Kimmel, J. R., Sueper, D., Jayne, J. T., Herndon, S. C., Trimborn, A. M., Williams, L. R., Wood, E. C., Middlebrook, A. M., Kolb, C. E., Baltensperger, U., and Worsnop, D. R.: Evolution of Organic Aerosols in the Atmosphere, Science, 326, 1525-1529, doi:10.1126/science.1180353, 2009.

Justesen, U.: Collision-induced fragmentation of deprotonated methoxylated flavonoids, obtained by electrospray ionization mass spectrometry, J. Mass Spectrom., 36, 169-178, doi:10.1002/jms.118, 2001.

Kalberer, M., Sax, M., and Samburova, V.: Molecular size evolution of oligomers in organic aerosols collected in urban atmospheres and generated in a smog chamber, Environ. Sci. Technol., 40, 5917-5922, doi:10.1021/es0525760, 2006.

Kessler, S. H., Smith, J. D., Che, D. L., Worsnop, D. R., Wilson, K. R., and Kroll, J. H.: Chemical Sinks of Organic Aerosol: Kinetics and Products of the Heterogeneous Oxidation of Erythritol and Levoglucosan, Environ. Sci. Technol., 44, 7005-7010, doi:10.1021/es101465m, 2010.

Kessler, S. H., Nah, T., Daumit, K. E., Smith, J. D., Leone, S. R., Kolb, C. E., Worsnop, D. R., Wilson, K. R., and Kroll, J. H.: OH-Initiated Heterogeneous Aging of Highly Oxidized Organic Aerosol, J. Phys. Chem. A, 116, 6358-6365, doi:10.1021/jp212131m, 2012.

Khwaja, H. A.: Atmospheric concentrations of carboxylic acids and related compounds at a semiurban site, Atmos. Environ., 29, 127-139, doi:10.1016/1352-2310(94)00211-3, 1995.
Kiss, G., Tombacz, E., Varga, B., Alsberg, T., and Persson, L.: Estimation of the average molecular weight of humic-like substances isolated from fine atmospheric aerosol, Atmos. Environ., 37, 3783-3794, doi:10.1016/s1352-2310(03)00468-0, 2003.

Konovalov, I. B., Beekmann, M., Kuznetsova, I. N., Yurova, A., and Zvyagintsev, A. M.: Atmospheric impacts of the 2010 Russian wildfires: integrating modelling and measurements of an extreme air pollution episode in the Moscow region, Atmos. Chem. Phys., 11, 10031-10056, doi:10.5194/acp-11-10031-2011, 2011.

Kourtchev, I., Ruuskanen, T. M., Keronen, P., Sogacheva, L., Dal Maso, M., Reissell, A., Chi, X., Vermeylen, R., Kulmala, M., Maenhaut, W., and Claeys, M.: Determination of isoprene and alpha-/beta-pinene oxidation products in boreal forest aerosols from Hyytiala, Finland: diel variations and possible link with particle formation events, Plant Biol., 10, 138-149, doi:10.1055/s2007-964945, 2008.

Kourtchev, I., Fuller, S., Aalto, J., Ruuskanen, T. M., McLeod, M. W., Maenhaut, W., Jones, R., Kulmala, M., and Kalberer, M.: Molecular Composition of Boreal Forest Aerosol from Hyytiälä, Finland, Using Ultrahigh Resolution Mass Spectrometry, Environ. Sci. Technol., 47, 4069-4079, doi:10.1021/es3051636, 2013.

Kroll, J. H., Donahue, N. M., Jimenez, J. L., Kessler, S. H., Canagaratna, M. R., Wilson, K. R., Altieri, K. E., Mazzoleni, L. R., Wozniak, A. S., Bluhm, H., Mysak, E. R., Smith, J. D., Kolb, C. E., and Worsnop, D. R.: Carbon oxidation state as a metric for describing the chemistry of atmospheric organic aerosol, Nature Chemistry, 3, 133-139, doi:10.1038/nchem.948, 2011.

Kückelmann, U., Warscheid, S., and Hoffmann, T.: On-line characterization of organic aerosols formed from biogenic precursors using atmospheric pressure chemical ionization mass spectrometry, Anal. Chem., 72, 1905-1912, doi:10.1021/ac991178a, 2000.

Kulmala, M., Hameri, K., Aalto, P. P., Makela, J. M., Pirjola, L., Nilsson, E. D., Buzorius, G., Rannik, U., Dal Maso, M., Seidl, W., Hoffman, T., Janson, R., Hansson, H. C., Viisanen, Y., Laaksonen, A., and O'Dowd, C. D.: Overview of the international project on biogenic aerosol formation in the boreal forest (BIOFOR), Tellus B, 53, 324-343, doi:10.1034/j.16000889.2001.530402.x, 2001.

Laskin, A., Laskin, J., and Nizkorodov, S. A.: Mass spectrometric approaches for chemical characterisation of atmospheric aerosols: critical review of the most recent advances, Environ. Chem., 9, 163-189, doi:10.1071/en12052, 2012.

Liang, C. K. and Pankow, J. F.: Gas/particle partitioning of organic compounds to environmental tobacco smoke: Partition coefficient measurements by desorption and comparison to urban particulate material, Environ. Sci. Technol., 30, 2800-2805, doi:10.1021/es960050x, 1996.

Ma, Y., Porter, R. A., Chappell, D., Russell, A. T., and Marston, G.: Mechanisms for the formation of organic acids in the gas-phase ozonolysis of 3-carene, Phys. Chem. Chem. Phys., 11, 41844197, doi:10.1039/b818750a, 2009.

Mitchum, R. K. and Korfmacher, W. A.: Atmospheric Pressure Ionization Mass Spectrometry, Anal. Chem., 55, 1485-1499, 1983.

Müller, L., Reinnig, M.-C., Naumann, K. H., Saathoff, H., Mentel, T. F., Donahue, N. M., and Hoffmann, T.: Formation of 3-methyl1,2,3-butanetricarboxylic acid via gas phase oxidation of pinonic acid - a mass spectrometric study of SOA aging, Atmos. Chem. Phys., 12, 1483-1496, doi:10.5194/acp-12-1483-2012, 2012. 
Net, S., Alvarez, E. G., Gligorovski, S., and Wortham, H.: Heterogeneous reactions of ozone with methoxyphenols, in presence and absence of light, Atmos. Environ., 45, 3007-3014, doi:10.1016/j.atmosenv.2011.03.026, 2011.

Nilsson, E. D., Paatero, J., and Boy, M.: Effects of air masses and synoptic weather on aerosol formation in the continental boundary layer, Tellus B, 53, 462-478, doi:10.1034/j.16000889.2001.530410.x, 2001.

Paatero, P. and Tapper, U.: Positive Matrix Factorization: a nonnegative factor model with optimal utilization of error estimates of data values, Environmetrics, 5, 111-126, 1994.

Pankow, J. F.: An Absorption Model of Gas/Particle Partitioning of Organic Compounds in the Atmosphere, Atmos. Environ., 28, 189-193, doi:10.1016/1352-2310(94)90093-0, 1994.

Pankow, J. F.: On the ability of the gas/particle partitioning constant K-p to consider the effects of mean MW and the presence of high MW compounds, Atmos. Environ., 45, 1213-1216, doi:10.1016/j.atmosenv.2010.11.041, 2011.

Pankow, J. F. and Asher, W. E.: SIMPOL.1: a simple group contribution method for predicting vapor pressures and enthalpies of vaporization of multifunctional organic compounds, Atmos. Chem. Phys., 8, 2773-2796, doi:10.5194/acp-8-27732008, 2008.

Portin, H., Mielonen, T., Leskinen, A., Arola, A., Parjala, E., Romakkaniemi, S., Laaksonen, A., Lehtinen, K. E. J., and Komppula, M.: Biomass burning aerosols observed in Eastern Finland during the Russian wildfires in summer 2010 - Part 1: In-situ aerosol characterization, Atmos. Environ., 47, 269-278, doi:10.1016/j.atmosenv.2011.10.067, 2012.

Pratt, K. A. and Prather, K. A.: Mass Spectrometry of Atmospheric Aerosols - Recent Developments and Applications. Part II: Online Mass Spectrometry Techniques, Mass Spectrom. Rev., 31, 17-48, doi:10.1002/mas.20330, 2012.

Riipinen, I., Yli-Juuti, T., Pierce, J. R., Petaja, T., Worsnop, D. R., Kulmala, M., and Donahue, N. M.: The contribution of organics to atmospheric nanoparticle growth, Nature Geosci., 5, 453-458, doi:10.1038/ngeo1499, 2012

Rolph, G. D.: Real-time Environmental Applications and Display sYstem (READY) Website: http://ready.arl.noaa.gov, NOAA Air Resources Laboratory, Silver Spring, MD, 2013.

Rossignol, S., Chiappini, L., Perraudin, E., Rio, C., Fable, S., Valorso, R., and Doussin, J. F.: Development of a parallel sampling and analysis method for the elucidation of gas/particle partitioning of oxygenated semi-volatile organics: a limonene ozonolysis study, Atmos. Meas. Tech., 5, 1459-1489, doi:10.5194/amt-51459-2012, 2012.

Russell, L. M., Takahama, S., Liu, S., Hawkins, L. N., Covert, D. S., Quinn, P. K., and Bates, T. S.: Oxygenated fraction and mass of organic aerosol from direct emission and atmospheric processing measured on the R/V Ronald Brown during TEXAQS/GoMACCS 2006, J. Geophys. Res., 114, D00F05, doi:10.1029/2008JD011275, 2009.

Sabine, C. L., Heimann, M., Artaxo, P., Bakker, D. C. E., Chen, C. A., Field, C. B., Gruber, N., Le Quéré, C., Prinn, R., Richey, J. E., Romero Lankao, P., Satahaye J. A., and Valentin, R.: Current Status and Past Trends of the Global Carbon Cycle, in: The global carbon cycle: Integrating humans, climate, and the natural world, edited by: Field, C. B. and Raupach, M. R., SCOPE, 62, Island Press, Washington, 17-44, 2004.
Shiraiwa, M. and Seinfeld, J. H.: Equilibration timescale of atmospheric secondary organic aerosol partitioning, Geophys. Res. Lett., 39, L24801, doi:10.1029/2012GL054008, 2012.

Shiraiwa, M., Ammann, M., Koop, T., and Pöschl, U.: Gas uptake and chemical aging of semisolid organic aerosol particles, P. Natl. Acad. Sci. USA, 108, 11003-11008, doi:10.1073/pnas.1103045108, 2011.

Simoneit, B. R. T., Rogge, W. F., Mazurek, M. A., Standley, L. J., Hildemann, L. M., and Cass, G. R.: Lignin Pyrolysis Products, Lignans, and Resin Acids as Specific Tracers of Plant Classes in Emissions from Biomass Combustion, Environ. Sci. Technol., 27, 2533-2541, doi:10.1021/es00048a034, 1993.

Solomon, S. (Ed.): The physical science basis: Contribution of Working Group I to the fourth assessment report of the Intergovernmental Panel on Climate Change, Assessment report/Intergovernmental Panel on Climate Change (IPCC), 4, Cambridge Univ. Press, Cambridge, 2007.

Spracklen, D. V., Bonn, B., and Carslaw, K. S.: Boreal forests, aerosols and the impacts on clouds and climate, Philos. T. Roy. Soc. a-Mathematical Physical and Engineering Sciences, 366, 4613-4626, doi:10.1098/rsta.2008.0201, 2008.

Szmigielski, R., Surratt, J. D., Gomez-Gonzalez, Y., van der Veken, P., Kourtchev, I., Vermeylen, R., Blockhuys, F., Jaoui, M., Kleindienst, T. E., Lewandowski, M., Offenberg, J. H., Edney, E. O., Seinfeld, J. H., Maenhaut, W., and Claeys, M.: 3-methyl1,2,3-butanetricarboxylic acid: An atmospheric tracer for terpene secondary organic aerosol, Geophys. Res. Lett., 34, L24811, doi:10.1029/2007g1031338, 2007.

Takahama, S., Johnson, A., and Russell, L. M.: Quantification of carboxylic acid and carbonyl functional groups in organic aerosol infrared absorbance spectra, Aerosol Sci. Technol., 47, 310-325, doi:10.1080/02786826.2012.752065, 2013.

Virtanen, A., Joutsensaari, J., Koop, T., Kannosto, J., Yli-Pirila, P., Leskinen, J., Makela, J. M., Holopainen, J. K., Pöschl, U., Kulmala, M., Worsnop, D. R., and Laaksonen, A.: An amorphous solid state of biogenic secondary organic aerosol particles, Nature, 467, 824-827, doi:10.1038/nature09455, 2010.

Vogel, A. L., Äijälä, M., Brüggemann, M., Ehn, M., Junninen, H., Petäjä, T., Worsnop, D. R., Kulmala, M., Williams, J., and Hoffmann, T.: Online atmospheric pressure chemical ionization ion trap mass spectrometry (APCI-IT-MSn) for measuring organic acids in concentrated bulk aerosol - a laboratory and field study, Atmos. Meas. Tech., 6, 431-443, doi:10.5194/amt-6-431-2013, 2013.

Warnke, J., Bandur, R., and Hoffmann, T.: Capillary-HPLC-ESIMS/MS method for the determination of acidic products from the oxidation of monoterpenes in atmospheric aerosol samples, Anal. Bioanal. Chem., 385, 34-45, doi:10.1007/s00216-0060340-6, 2006.

Warscheid, B. and Hoffmann, T.: Direct analysis of highly oxidised organic aerosol constituents by on-line ion trap mass spectrometry in the negative-ion mode, Rapid Communications in Mass Spectrometry, 16, 496-504, doi:10.1002/rcm.602, 2002.

Williams, B. J., Goldstein, A. H., Kreisberg, N. M., and Hering, S. V.: In situ measurements of gas/particle-phase transitions for atmospheric semivolatile organic compounds, P. Natl. Acad. Sci USA, 107, 6676-6681, doi:10.1073/pnas.0911858107, 2010.

Williams, J., Crowley, J., Fischer, H., Harder, H., Martinez, M., Petäjä, T., Rinne, J., Bäck, J., Boy, M., Dal Maso, M., Hakala, 
J., Kajos, M., Keronen, P., Rantala, P., Aalto, J., Aaltonen, H., Paatero, J., Vesala, T., Hakola, H., Levula, J., Pohja, T., Herrmann, F., Auld, J., Mesarchaki, E., Song, W., Yassaa, N., Nölscher, A., Johnson, A. M., Custer, T., Sinha, V., Thieser, J., Pouvesle, N., Taraborrelli, D., Tang, M. J., Bozem, H., Hosaynali-Beygi, Z., Axinte, R., Oswald, R., Novelli, A., Kubistin, D., Hens, K., Javed, U., Trawny, K., Breitenberger, C., Hidalgo, P. J., Ebben, C. J., Geiger, F. M., Corrigan, A. L., Russell, L. M., Ouwersloot, H. G., Vilà-Guerau de Arellano, J., Ganzeveld, L., Vogel, A., Beck, M., Bayerle, A., Kampf, C. J., Bertelmann, M., Köllner, F., Hoffmann, T., Valverde, J., González, D., Riekkola, M.-L., Kulmala, M., and Lelieveld, J.: The summertime Boreal forest field measurement intensive (HUMPPA-COPEC-2010): an overview of meteorological and chemical influences, Atmos. Chem. Phys., 11, 10599-10618, doi:10.5194/acp-11-10599-2011, 2011.

Yasmeen, F., Vermeylen, R., Szmigielski, R., Iinuma, Y., Böge, O., Herrmann, H., Maenhaut, W., and Claeys, M.: Terpenylic acid and related compounds: precursors for dimers in secondary organic aerosol from the ozonolysis of $\alpha$ - and $\beta$-pinene, Atmos. Chem. Phys., 10, 9383-9392, doi:10.5194/acp-10-9383-2010, 2010.

Yasmeen, F., Szmigielski, R., Vermeylen, R., Gomez-Gonzalez, Y., Surratt, J. D., Chan, A. W. H., Seinfeld, J. H., Maenhaut, W., and Claeys, M.: Mass spectrometric characterization of isomeric terpenoic acids from the oxidation of alpha-pinene, beta-pinene, d-limonene, and Delta(3)-carene in fine forest aerosol, J. Mass Spectrom., 46, 425-442, doi:10.1002/jms.1911, 2011.

Yasmeen, F., Vermeylen, R., Maurin, N., Perraudin, E., Doussin, J.-F., and Claeys, M.: Characterisation of tracers for aging of $\alpha$-pinene secondary organic aerosol using liquid chromatography/negaive ion electrospray ionisation mass spectrometry, Environ. Chem., 9, 236-246, doi:10.1071/EN11148, 2012.

Yassaa, N., Song, W., Lelieveld, J., Vanhatalo, A., Bäck, J., and Williams, J.: Diel cycles of isoprenoids in the emissions of Norway spruce, four Scots pine chemotypes, and in Boreal forest ambient air during HUMPPA-COPEC-2010, Atmos. Chem. Phys., 12, 7215-7229, doi:10.5194/acp-12-7215-2012, 2012.
Yatavelli, R. L. N., Lopez-Hilfiker, F., Wargo, J. D., Kimmel, J. R., Cubison, M. J., Bertram, T. H., Jimenez, J. L., Gonin, M., Worsnop, D. R., and Thornton, J. A.: A Chemical Ionization High-Resolution Time-of-Flight Mass Spectrometer Coupled to a Micro Orifice Volatilization Impactor (MOVI-HR-ToF-CIMS) for Analysis of Gas and ParticlePhase Organic Species, Aerosol Sci. Technol., 46, 1313-1327, doi:10.1080/02786826.2012.712236, 2012.

Yu, J. Z., Flagan, R. C., and Seinfeld, J. H.: Identification of products containing $-\mathrm{COOH},-\mathrm{OH}$, and $-\mathrm{C}=\mathrm{O}$ in atmospheric oxidation of hydrocarbons, Environ. Sci. Technol., 32, 2357-2370, doi:10.1021/es980129x, 1998.

Yu, J. Z., Cocker, D. R., Griffin, R. J., Flagan, R. C., and Seinfeld, J. H.: Gas-phase ozone oxidation of monoterpenes: Gaseous and particulate products, J. Atmos. Chem., 34, 207-258, doi:10.1023/a:1006254930583, 1999.

Zahardis, J., Geddes, S., and Petrucci, G. A.: Improved Understanding of Atmospheric Organic Aerosols via Innovations in Soft Ionization Aerosol Mass Spectrometry, Anal. Chem., 83, 24092415, doi:10.1021/ac102737k, 2011.

Zhang, Q., Jimenez, J. L., Canagaratna, M. R., Allan, J. D., Coe, H., Ulbrich, I., Alfarra, M. R., Takami, A., Middlebrook, A M., Sun, Y. L., Dzepina, K., Dunlea, E., Docherty, K., DeCarlo, P. F., Salcedo, D., Onasch, T., Jayne, J. T., Miyoshi, T., Shimono, A., Hatakeyama, S., Takegawa, N., Kondo, Y., Schneider, J., Drewnick, F., Borrmann, S., Weimer, S., Demerjian, K., Williams, P., Bower, K., Bahreini, R., Cottrell, L., Griffin, R. J., Rautiainen, J., Sun, J. Y., Zhang, Y. M., and Worsnop, D. R.: Ubiquity and dominance of oxygenated species in organic aerosols in anthropogenically-influenced Northern Hemisphere midlatitudes, Geophys. Res. Lett., 34, L13801, doi:10.1029/2007gl029979, 2007.

Zhang, R.: Getting to the Critical Nucleus of Aerosol Formation, Science, 328, 1366-1367, doi:10.1126/science.1189732, 2010. 